\title{
Synthesis and characterization of fluorinated azadipyrromethene complexes as acceptors for organic photovoltaics
}

\author{
Forrest S. Etheridge ${ }^{1}$, Roshan J. Fernando ${ }^{1}$, Sandra Pejić ${ }^{1}$, Matthias Zeller ${ }^{2}$ \\ and Geneviève Sauvé*1
}

\author{
Full Research Paper \\ Address: \\ 1Department of Chemistry, Case Western Reserve University, \\ Cleveland, Ohio 44106, United States and ${ }^{2}$ Department of Chemistry, \\ Purdue University, West Lafayette, Indiana 47907, United States \\ Email: \\ Geneviève Sauvé* - genevieve.sauve@case.edu \\ * Corresponding author \\ Keywords: \\ dye; fluorine; near-IR absorber; non-fullerene acceptor; zinc(II) \\ complex
}

\author{
Beilstein J. Org. Chem. 2016, 12, 1925-1938. \\ doi:10.3762/bjoc. 12.182 \\ Received: 04 June 2016 \\ Accepted: 11 August 2016 \\ Published: 29 August 2016 \\ Guest Editor: D. J. Jones \\ (c) 2016 Etheridge et al.; licensee Beilstein-Institut. \\ License and terms: see end of document.
}

This article is part of the Thematic Series "Organo photovoltaics".

\begin{abstract}
Homoleptic zinc(II) complexes of di(phenylacetylene)azadipyrromethene (e.g., Zn(WS3) 2 ) are potential non-fullerene electron acceptors for organic photovoltaics. To tune their properties, fluorination of $\mathrm{Zn}(\mathrm{WS} 3)_{2}$ at various positions was investigated. Three fluorinated azadipyrromethene-based ligands were synthesized with fluorine at the para-position of the proximal and distal phenyl groups, and at the pyrrolic phenylacetylene moieties. Additionally, a $\mathrm{CF}_{3}$ moiety was added to the pyrrolic phenyl positions to study the effects of a stronger electron withdrawing unit at that position. The four ligands were chelated with zinc(II) and $\mathrm{BF}_{2}^{+}$and the optical and electrochemical properties were studied. Fluorination had little effect on the optical properties of both the zinc(II) and $\mathrm{BF}_{2}^{+}$complexes, with $\lambda_{\max }$ in solution around $755 \mathrm{~nm}$ and $785 \mathrm{~nm}$, and high molar absorptivities of $100 \times 10^{3} \mathrm{M}^{-1} \mathrm{~cm}^{-1}$ and $50 \times 10^{3} \mathrm{M}^{-1} \mathrm{~cm}^{-1}$, respectively. Fluorination of $\mathrm{Zn}(\mathrm{WS} 3)_{2}$ raised the oxidation potentials by $0.04 \mathrm{~V}$ to $0.10 \mathrm{~V}$, and the reduction potentials by $0.01 \mathrm{~V}$ to $0.10 \mathrm{~V}$, depending on the position and type of substitution. The largest change was observed for fluorine substitution at the proximal phenyl groups and $\mathrm{CF}_{3}$ substitution at the pyrrolic phenylacetylene moieties. The later complexes are expected to be stronger electron acceptors than $\mathrm{Zn}(\mathrm{WS} 3)_{2}$, and may enable charge transfer from other conjugated polymer donors that have lower energy levels than poly(3-hexylthiophene) (P3HT).
\end{abstract}

\section{Introduction}

Azadipyrromethenes (ADPs) (Figure 1a) are a class of monoanionic bidentate ligands with strong absorption in the visible and near IR range. Their absorbance and emission properties can be readily tuned through structural modifications and chelation [1-4]. $\mathrm{BF}_{2}{ }^{+}$-chelated ADP derivatives (Figure 1b) in particular have drawn interest for photodynamic therapy, bio-imaging and light harvesting applications [5-8].

We have shown that derivatives of $\mathrm{Zn}(\mathrm{ADP})_{2}$ are promising electron acceptors for organic photovoltaics (OPVs) $[9,10]$. 
distal phenyl groups

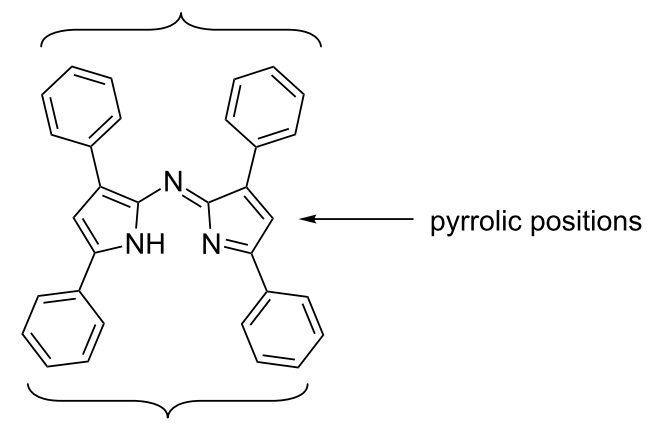

proximal phenyl groups

a) Azadipyrromethene (ADP)

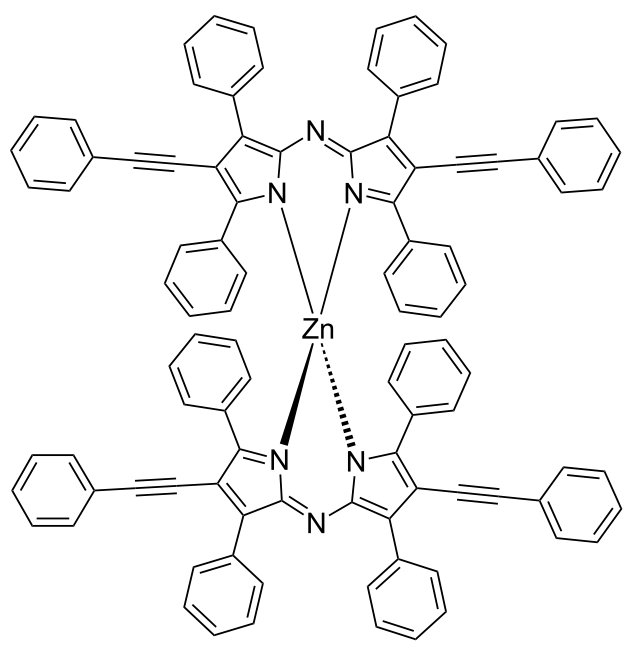

c) $\mathrm{Zn}(\mathrm{WS} 3)_{2}$

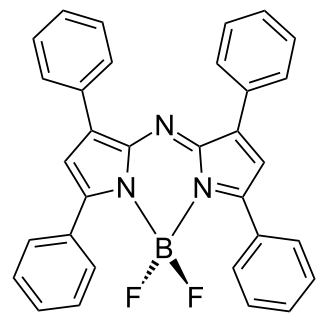

b) $\mathrm{BF}_{2}(\mathrm{ADP})$

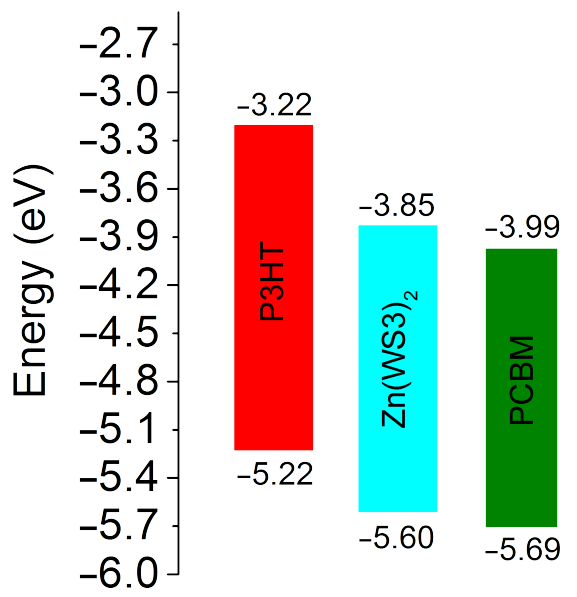

d) HOMO/LUMO estimates

Figure 1: a) Azadipyrromethene ligand labeling positioning; b and c) chelates; d) estimated HOMO/LUMO energy levels [9].

A series of zinc(II) derivatives with various pyrrolic substitutions showed power conversion efficiencies (PCEs) ranging from $2.2-4.1 \%$ when blended with poly(3-hexylthiophene) (P3HT), and the highest PCE was obtained with $\mathrm{Zn}(\mathrm{WS} 3)_{2}$, shown in Figure 1c $[9,10]$. In comparison, free ligands and $\mathrm{BF}_{2}{ }^{+}$chelates showed negligible power conversion efficiencies, and $\mathrm{Zn}(\mathrm{ADP})_{2}$ gave a maximum efficiency of $1.4 \%$ [11]. Free ligands and $\mathrm{BF}_{2}{ }^{+}$chelates tend to self-aggregate too much, leading to large scale phase separation with P3HT and low PCEs. Chelation with zinc(II) lowers the tendency to self-aggregate, but $\mathrm{Zn}(\mathrm{ADP})_{2}$ still shows some large aggregates in blend films [10]. The addition of pyrrolic phenylacetylene substituents further helped to break the aggregation and to create a favorable nanoscale phase separation in blend films, leading to higher PCEs $[9,10]$. DFT calculations show that $\mathrm{Zn}(\mathrm{WS} 3)_{2}$ is a very large and non-planar molecule with low electron transfer reorganization energy, further supporting its potential to replace fullerenes in OPVs [12]. However, the HOMO and LUMO energy levels of $\mathrm{Zn}(\mathrm{WS} 3)_{2}$ in solution are higher than that of the most popular electron acceptor phenyl- $\mathrm{C}_{61}$-butyric acid methyl ester (PCBM, Figure 1d). Decreasing the energy levels of the parent $\mathrm{Zn}(\mathrm{WS} 3)_{2}$ would enable this new class of acceptors to be paired with other polymer donors that have lower HOMO and LUMO energy levels than P3HT.

One substituent used to modify the properties of molecules without drastically altering the structure is fluorine, which is a unique element due to its small size and high electronegativity, with many applications in pharmaceuticals and materials [1315]. Its use as a hydrogen replacement has garnered wide use in industrial applications for high thermal stability and surface effects, most notably with polytetrafluoroethylene (PTFE) [16]. The small size and strong electron-withdrawing properties of fluorine make it ideally suited to tune the molecular orbital 
(MO) energy levels of polymer donors in OPVs without major influence on the structure [17-22]. In several cases, the addition of fluorine decreases the energy of the highest occupied molecular orbitals (HOMO), thereby enhancing the open-circuit voltages $\left(V_{\text {oc }}\right)$ and PCEs [17,23-26]. A 2014 investigation by Luscombe and co-workers showed that a fluorine substitution lowered the charge transfer exciton (CTE) binding energy, in turn creating more free carriers and higher PCEs [19]. Additionally, enhancements to the short-circuit current density $\left(J_{\mathrm{sc}}\right), V_{\mathrm{oc}}$, and fill-factor (FF) in OPVs have been attributed to the addition of fluorine substituents [17,18,20,21,27-29].

While fluorinated polymer donors are well known, fluorinated n-type materials are less common [13,30,31]. Nevertheless, fluorinated n-type materials have been shown to exhibit promising characteristics in devices. For instance, the addition of fluorinated groups to naphthalene diimide (NDI) and perylene diimide (PDI) derivatives increased the reduction potentials (more positive), allowed for air-stable fabrication of organic field effect transistors (OFETs), and showed promise in solar cells $[13,32]$. Some homoleptic metal complexes, such as $\operatorname{Ir}(\mathrm{III})$ phenylpyridine-based complexes, are favored for their use in light-emitting devices and the fluorinated derivatives allow access to triplet state blue light-emitters [13].

This work further investigates the effects of fluorination in n-type materials for OPVs. A series of selectively fluorinated ADP derivatives based on WS3 were synthesized (Figure 2). To understand the effect of the fluorination position, a single fluorine atom was added at three places: at the proximal phenyl position (L1), at the distal phenyl group (L2), and at the pyrrolic phenylacetylene moiety (L3). At the latter position, the degree of fluorination was further explored with the addition of $\mathrm{CF}_{3}$ (L4). These four fluorinated derivatives were then chelated with both $\mathrm{BF}_{2}{ }^{+}$and zinc(II) (Scheme 2, see below), and their optical and electrochemical properties were studied. $\mathrm{The} \mathrm{BF}_{2}{ }^{+}$chelates were included in this study because they may be useful near-IR absorbers for other light-harvesting applications. The fluorine substitutions had little effect on the optical properties of the $\mathrm{BF}_{2}{ }^{+}$and zinc(II) chelates, and only had a small effect on the electrochemical properties, with the largest increase in oxidation and reduction potentials of $0.1 \mathrm{~V}$ observed for L1 and L4 chelates compared to WS3 chelates. Zinc(II) chelates of L1 and L4 are expected to be stronger electron acceptors than

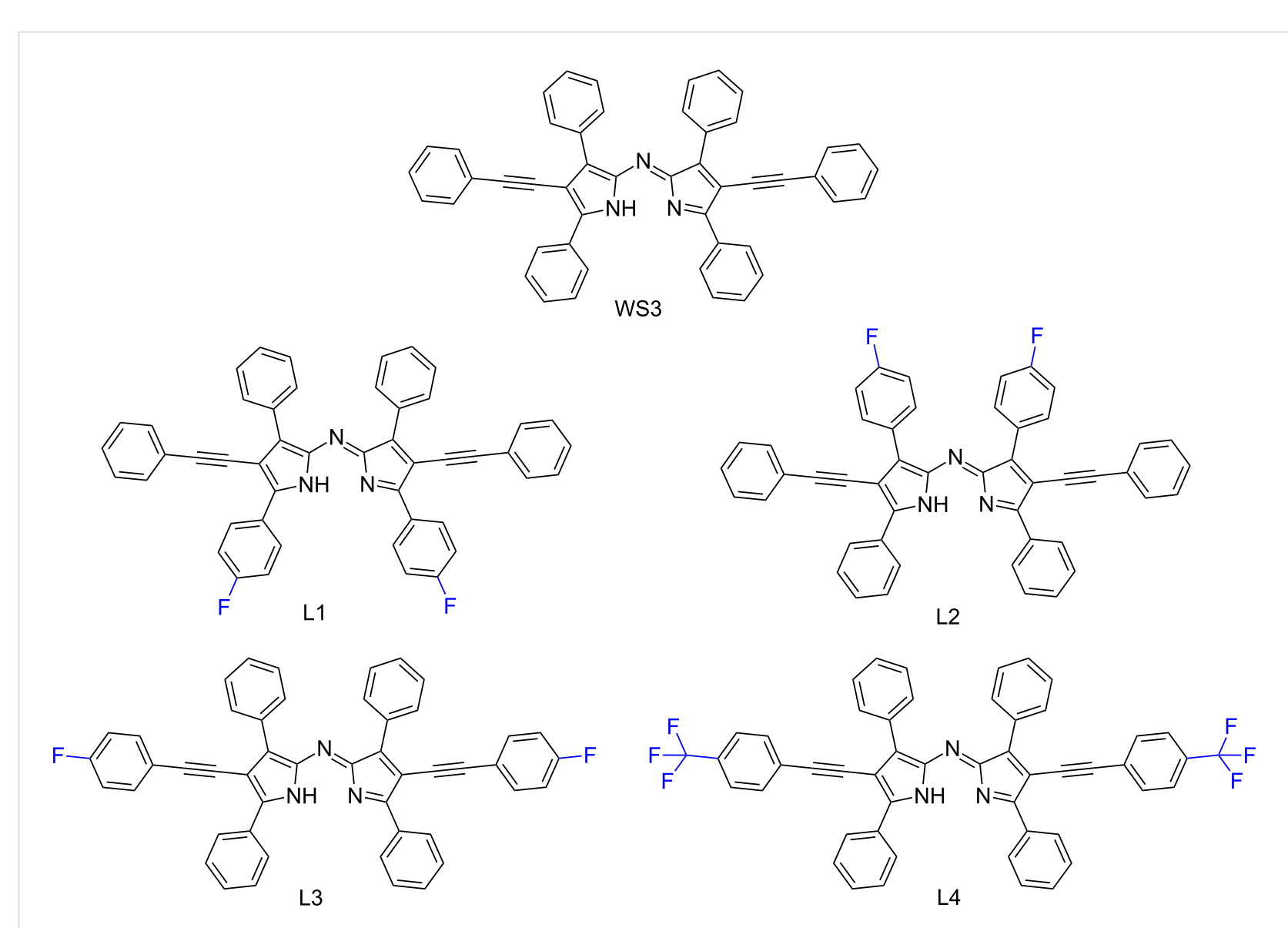

Figure 2: Chemical structures of the fluorinated ADP derivatives of WS3 explored in the study. 
$\mathrm{Zn}(\mathrm{WS} 3)_{2}$, and may enable charge transfer from other conjugated polymer donor that have lower energy levels than P3HT.

\section{Results and Discussion Synthesis}

The synthesis of ADP was carried out according to literature procedures $[9,33]$. The ADP-analogs with fluorine at the proximal or distal phenyl positions (L1-ADP and L2-ADP) were synthesized in a similar fashion with the respective fluorinated chalcones (Scheme 1). In this case, the nitro intermediates of the fluorinated chalcones could not be isolated as a solid powder, so the synthesis was carried forward assuming complete conversion from the first reaction.

To install phenylacetylene groups, iodination of the ADP derivatives was done according to literature procedures and purified by washing with chloroform in good yield [5,33,34]. Stille cross-coupling with the appropriate tributyltin-phenylacetylene analogs afforded the WS3 derivatives in good yield (Scheme 1). We chose to utilize Stille coupling instead of Sonogashira cou- pling because we had previously found that this method gives higher yields for installing phenylethynyl pyrrolic substituents [9]. The fluorinated tributyltinphenylacetylene analogs for the synthesis of L3 and L4 were synthesized according to literature procedures and used without purification [35,36]. The Stille cross coupling reactions for the synthesis of L3 and L4 were monitored by MALDI-TOF-MS and were found to not be complete after increasing the reaction time to $48 \mathrm{~h}$, so the reaction time was increased to $96 \mathrm{~h}$ with the addition of more catalyst and tributyltin reactant after $48 \mathrm{~h}$. These modifications were deemed necessary to push the reaction towards completion and aid in purification of the free ligand. The free ligands were isolated from the crude mixture by rotary evaporation and purified by trituration with cold methanol and the remaining solid was washed with cold ether. Due to the lowered solubility of the iodinated ADP derivatives and the free ligands in organic solvents, the identity of these compounds was confirmed only by MADLI-TOF-MS. These modifications allowed for the synthesis of all fluorinated WS3 derivatives in good yield with sufficient purity for chelation.<smiles>[X]c1ccc(/C=C/C(=O)c2ccc([X])cc2)cc1</smiles>

1) $\mathrm{CH}_{3} \mathrm{NO}_{2}$, DEA $\mathrm{MeOH}$, reflux, $24 \mathrm{~h}$

2) ammonium acetate (35 equiv) $n$-butanol, reflux, $24 \mathrm{~h}$

chalcone<smiles>[X]c1ccc(C2=N/C(=N\c3[nH]c(-c4ccc([Y])cc4)c(I)c3-c3ccc([X])cc3)C(c3ccc([X])cc3)=C2I)cc1</smiles>

L\#-ADPI ${ }_{2}$<smiles>[Z]c1ccc(C#C[SbH2])cc1</smiles>

$\mathrm{Pd}\left(\mathrm{PPh}_{3}\right)_{4}$

distilled xylenes $125^{\circ} \mathrm{C}, \mathrm{N}_{2}$, (time in legend)<smiles>[X]c1ccc(C2=CC(c3ccc([X])cc3)=N/C2=N\c2[nH]c(-c3ccc([Y])cc3)cc2-c2ccc([Y])cc2)cc1</smiles>
NIS $\mathrm{CHCl}_{3}$, acetic acid $\mathrm{N}_{2}$, rt, $24 \mathrm{~h}$

L\#-ADP

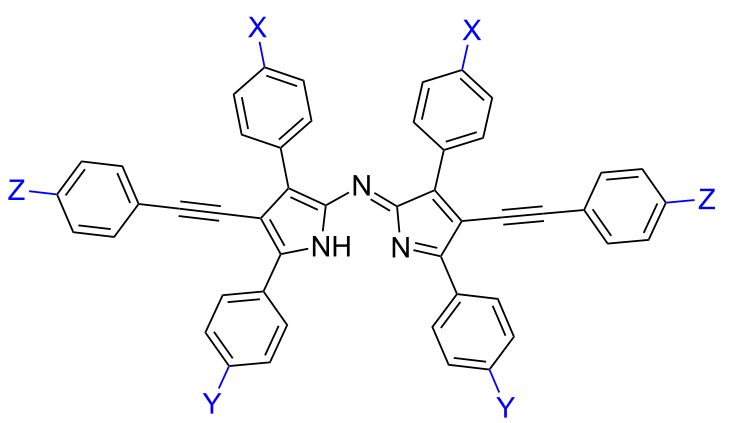

$$
\begin{array}{ll}
\text { WS3 } & X=H, Y=H, Z=H, 24 h \\
\text { L1 } & X=H, Y=F, Z=H, 24 h \\
\text { L2 } & X=F, Y=H, Z=H, 24 h \\
\text { L3 } & X=H, Y=H, Z=F, 96 h \\
\text { L4 } \quad X=H, Y=H, Z=C F_{3}, 96 h
\end{array}
$$




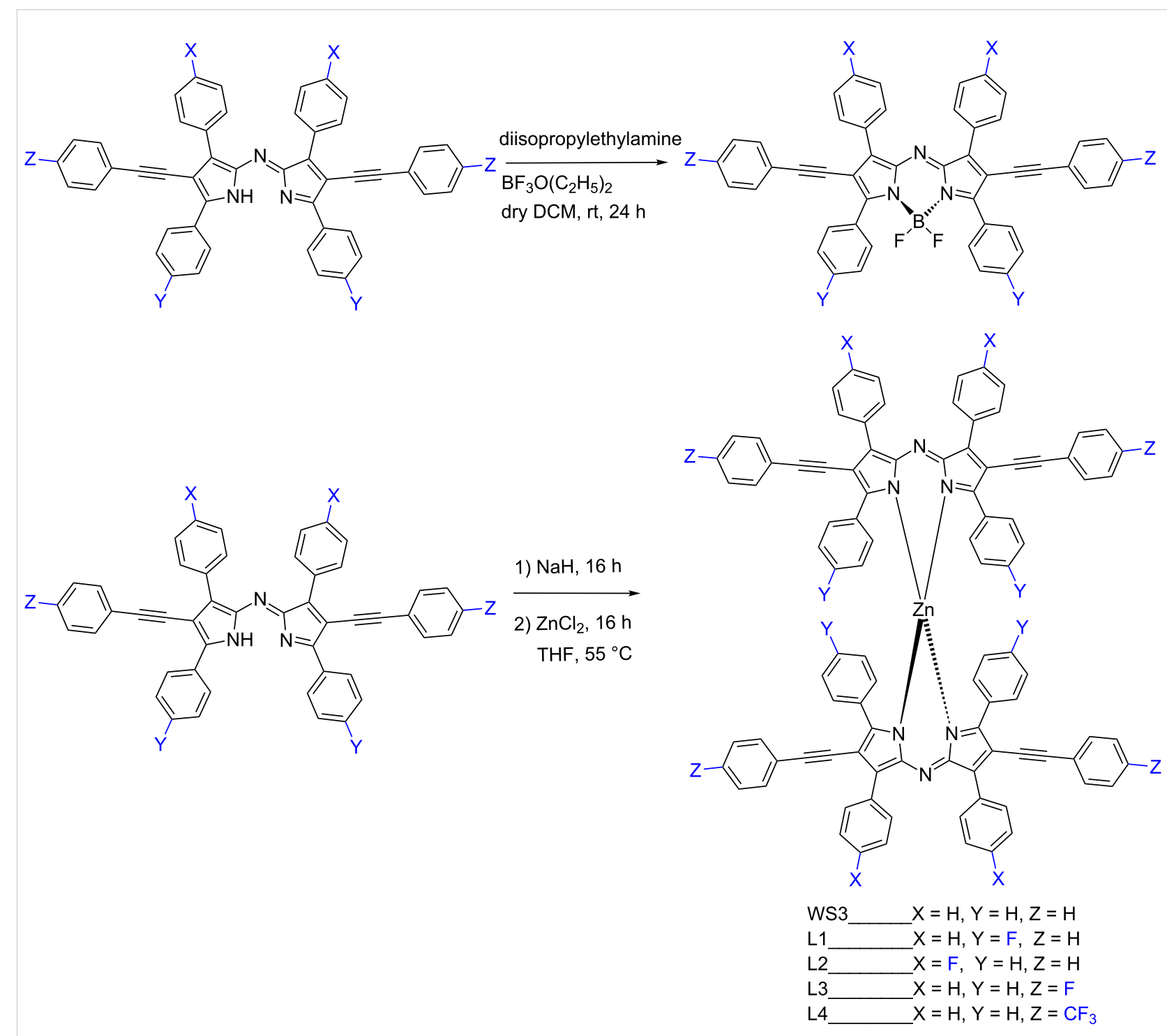

Scheme 2: Generic chelation scheme yielding $\mathrm{WS}_{3}-$ based $\mathrm{BF}_{2}{ }^{+}$and zinc(II) complexes.

The $\mathrm{BF}_{2}{ }^{+}$chelation was carried out according to the literature procedures in moderate yields (Scheme 2) [2,5]. For the zinc(II) chelation, the reaction was changed from a reaction using $\mathrm{Zn}(\mathrm{OAc})_{2}$ to a 2-step, one pot reaction with sodium hydride in tetrahydrofuran, followed by the addition of zinc(II) chloride. Zinc(II) and $\mathrm{BF}_{2}{ }^{+}$chelates were purified by silica gel column chromatography to isolate the chelates as blue solids and the identity and purity was confirmed by NMR spectroscopy, MALDI-TOF-MS and elemental analysis. In the case of L2, the pure $\mathrm{BF}_{2}^{+}$chelate could not be isolated by column chromatography, and will therefore be omitted from further analysis.

The thermal stability of the zinc(II) complexes was examined by thermal gravity analysis and the results are shown in Figure 3. The fluorinated complexes had weight loss profiles

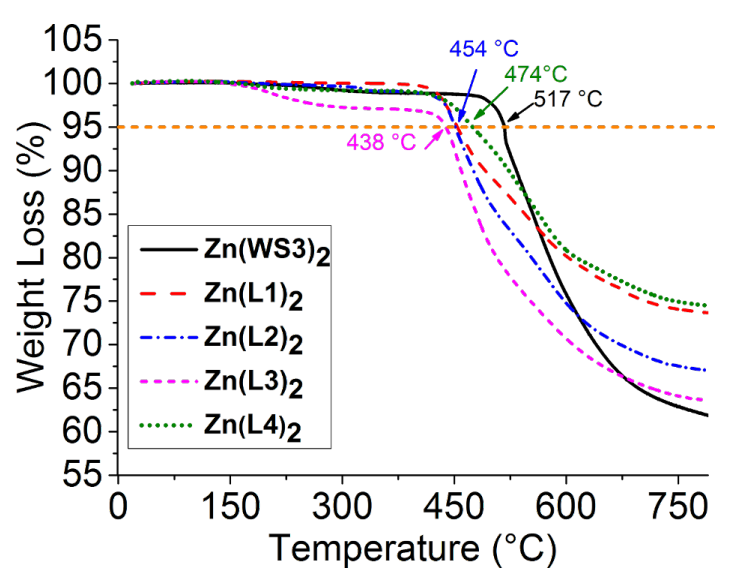

Figure 3: TGA spectra for the zinc(II) complexes. 
similar to each other with a $5 \%$ loss between $438{ }^{\circ} \mathrm{C}$ and $474{ }^{\circ} \mathrm{C}$, all lower than that of the unfluorinated $\mathrm{Zn}(\mathrm{WS} 3)_{2}$ at $517^{\circ} \mathrm{C}$.

\section{Optical properties}

Optical studies for the zinc(II) and $\mathrm{BF}_{2}{ }^{+}$complexes were performed in chloroform solutions and with spun-cast films on microscope slides. Like the solid powders, all of the solutions and films were dark blue. Solution and film optical properties for zinc(II) and $\mathrm{BF}_{2}{ }^{+}$chelates are summarized in Table 1 . The molar absorptivity spectra in chloroform solutions for zinc(II) and $\mathrm{BF}_{2}{ }^{+}$chelates are reported in Figure $4 \mathrm{a}$ and Figure $4 b$, respectively.

The absorption spectra of the zinc(II) chelates are all similar. In most cases, the $\lambda_{\max }$ and $\lambda_{\text {onset }}$ values remain consistent with $\mathrm{Zn}(\mathrm{WS} 3)_{2}$ around $670 \mathrm{~nm}$ and $755 \mathrm{~nm}$, respectively. An exception is $\mathrm{Zn}(\mathrm{L} 4)_{2}$, with $\lambda_{\max }$ and $\lambda_{\text {onset }}$ blue-shifted by $10 \mathrm{~nm}$ compared to $\mathrm{Zn}(\mathrm{WS} 3)_{2}$. This hypsochromic shift is consistent with other cases where a highly polarized $\mathrm{CF}_{3}$ group is added para to the conjugated structure [13,37]. Regardless of fluorination, the extinction coefficients are all near $100 \times 10^{3} \mathrm{M}^{-1} \mathrm{~cm}^{-1}$, showing the strong absorption properties of the WS3-core.

Solutions of $\mathrm{BF}_{2}{ }^{+}$chelates show a consistent trend compared with the solutions of zinc(II) chelates. The $\lambda_{\max }$ and $\lambda_{\text {onset }}$ values of $\mathrm{BF}_{2}(\mathrm{WS} 3), \mathrm{BF}_{2}(\mathrm{~L} 1)$, and $\mathrm{BF}_{2}(\mathrm{~L} 3)$ are $\approx 730 \mathrm{~nm}$ and $\approx 780 \mathrm{~nm}$, respectively. Consistent with that of the zinc(II) chelate solutions, $\lambda_{\max }$ of $\mathrm{BF}_{2}$ (L4) is $15 \mathrm{~nm}$ blue shifted compared to $\mathrm{BF}_{2}$ (WS3), showing a slightly greater effect from $\mathrm{CF}_{3}$ in the $\mathrm{BF}_{2}{ }^{+}$chelate. Molar absorptivities of the compounds vary from $49 \times 10^{3} \mathrm{M}^{-1} \mathrm{~cm}^{-1}$ for $\mathrm{BF}_{2}(\mathrm{WS} 3)$ to $66 \times 10^{3} \mathrm{M}^{-1} \mathrm{~cm}^{-1}$ for $\mathrm{BF}_{2}(\mathrm{~L} 4)$.
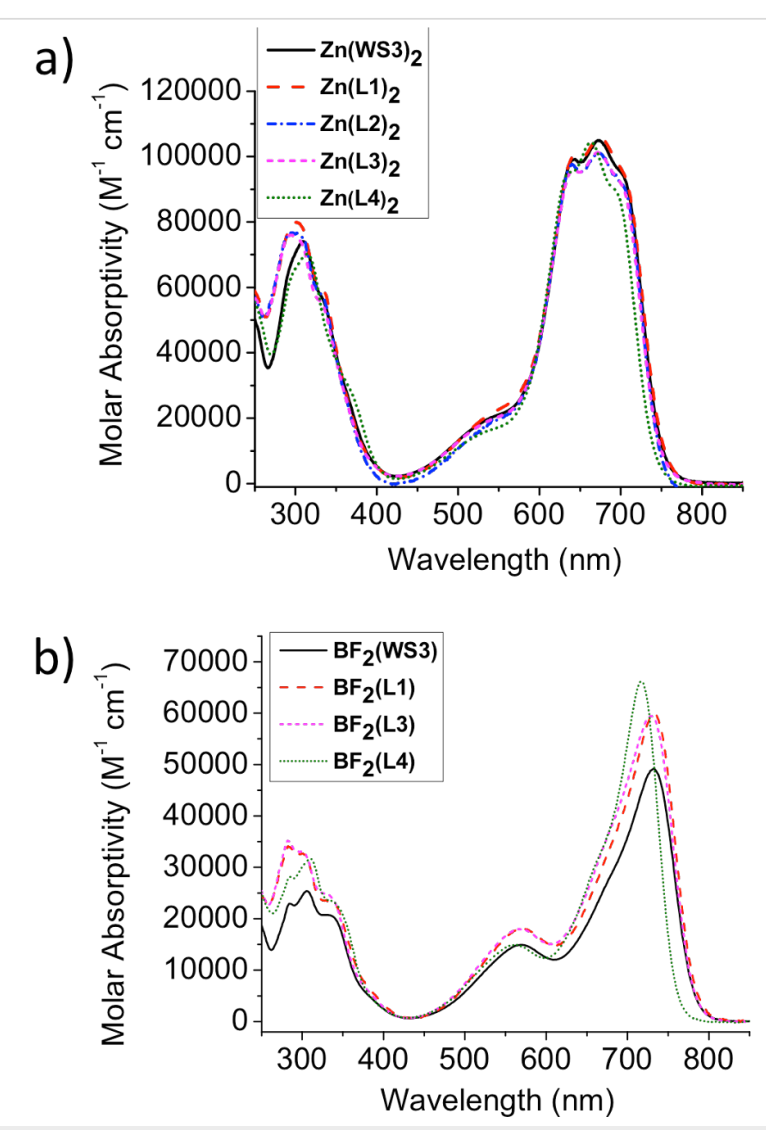

Figure 4: Molar absorptivities in chloroform solutions of a) zinc(II) chelates b) $\mathrm{BF}_{2}{ }^{+}$chelates.

Films of the zinc(II) and $\mathrm{BF}_{2}{ }^{+}$chelates were made in order to better understand the optical properties of the materials in devices, and the properties are summarized in Table 1. Normalized absorption spectra of zinc(II) and $\mathrm{BF}_{2}{ }^{+}$chelate films are reported in Figure 5a and Figure 5b, respectively. Following the same trend as the zinc(II) chelate solutions, the zinc(II) chelate

Table 1: Summary of optical properties of zinc(II) and $\mathrm{BF}_{2}{ }^{+}$chelates in solution and film.

\begin{tabular}{|c|c|c|c|c|}
\hline & \multicolumn{2}{|c|}{ Solution } & \multicolumn{2}{|c|}{ Film } \\
\hline & $\lambda_{\max }(\mathrm{nm})\left(\varepsilon, \times 10^{3} \mathrm{M}^{-1} \mathrm{~cm}^{-1}\right)$ & $\lambda_{\text {onset }}(\mathrm{nm})$ & $\lambda_{\max }(\mathrm{nm})$ & $\lambda_{\text {onset }}(\mathrm{nm})$ \\
\hline $\mathrm{Zn}(\mathrm{WS} 3)_{2}$ & $310(74), 664(99), 674(105)$ & 757 & 696 & 791 \\
\hline $\mathrm{BF}_{2}(\mathrm{WS} 3)$ & $732(49)$ & 782 & 759 & 835 \\
\hline $\mathrm{Zn}(\mathrm{L} 1)_{2}$ & $302(80), 643(100), 674(106)$ & 759 & 695 & 785 \\
\hline $\mathrm{BF}_{2}(\mathrm{~L} 1)$ & $732(60)$ & 783 & 755 & 829 \\
\hline $\mathrm{Zn}(\mathrm{L} 2)_{2}$ & $302(77), 640(98), 672(101)$ & 757 & 697 & 780 \\
\hline $\mathrm{BF}_{2}(\mathrm{~L} 2)$ & - & - & - & - \\
\hline $\mathrm{Zn}(\mathrm{L} 3)_{2}$ & $294(76), 642(96), 672(101)$ & 755 & 692 & 778 \\
\hline $\mathrm{BF}_{2}(\mathrm{~L} 3)$ & $729(59)$ & 783 & 770 & 868 \\
\hline $\mathrm{Zn}(\mathrm{L} 4)_{2}$ & $314(70), 663(104)$ & 746 & 676 & 769 \\
\hline $\mathrm{BF}_{2}(\mathrm{~L} 4)$ & $717(66)$ & 763 & 669 & 800 \\
\hline
\end{tabular}




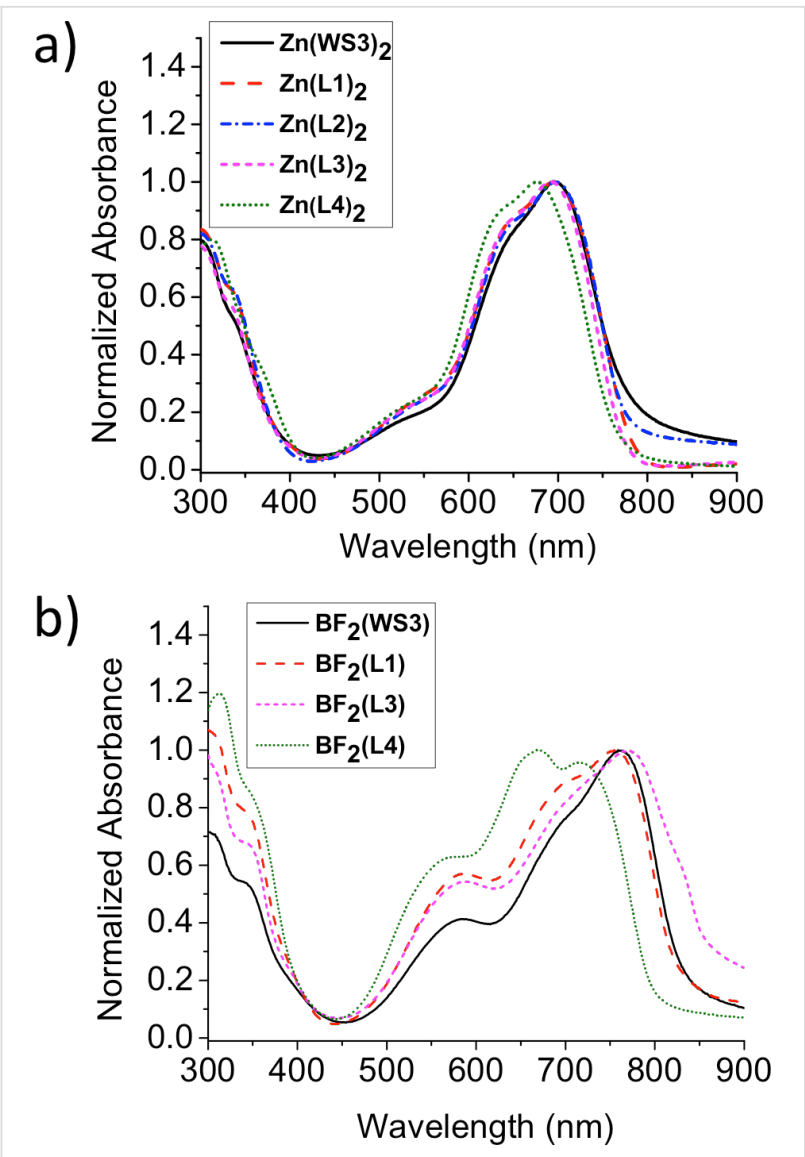

Figure 5: Normalized absorbance from spun-coat chloroform solution on microscope glass of a) zinc(II) chelates b) $\mathrm{BF}_{2}{ }^{+}$chelates.

films exhibited consistent $\lambda_{\max }$ values of $\approx 695 \mathrm{~nm}$, excluding

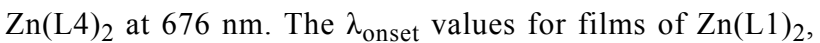
$\mathrm{Zn}(\mathrm{L} 2)_{2}, \mathrm{Zn}(\mathrm{L} 3)_{2}$, and $\mathrm{Zn}(\mathrm{L} 4)_{2}$ are 785, 780, 778, and $769 \mathrm{~nm}$, respectively, all blue shifted compared to $\lambda_{\text {onset }}$ of $\mathrm{Zn}(\mathrm{WS} 3)_{2}$ at $791 \mathrm{~nm}$. The shapes of all the curves remain consistent with a broad absorption from 500 to $800 \mathrm{~nm}$, good for OPV applications.
All $\mathrm{BF}_{2}{ }^{+}$chelate films exhibit broadening compared to solutions, with an absorbance ranging from 450 to $900 \mathrm{~nm}$. The $\lambda_{\max }$ values for $\mathrm{BF}_{2}(\mathrm{WS} 3)$ and $\mathrm{BF}_{2}(\mathrm{~L} 1)$ are similar at 759 and $755 \mathrm{~nm}$, respectively. The onset values for the two films are also similar at 835 and $829 \mathrm{~nm}$, respectively. Films of $\mathrm{BF}_{2}(\mathrm{~L} 3)$ and $\mathrm{BF}_{2}(\mathrm{~L} 4)$ show marked differences from two different fluorine modifications at the same position. $\mathrm{In}_{\mathrm{BF}_{2}}(\mathrm{~L} 3)$, the $\lambda_{\max }$ and $\lambda_{\text {onset }}$ are recorded at 770 and $868 \mathrm{~nm}$, respectively. Compared to $\mathrm{BF}_{2}$ (WS3), there is a small $11 \mathrm{~nm}$ bathochromic shift of $\lambda_{\max }$. For $\mathrm{BF}_{2}(\mathrm{~L} 4), \lambda_{\max }$ and $\lambda_{\text {onse }}$ are observed at 669 and $800 \mathrm{~nm}$, respectively. Compared to $\lambda_{\max }$ of $\mathrm{BF}_{2}(\mathrm{WS} 3), \mathrm{BF}_{2}(\mathrm{~L} 4)$ exhibits a large hypsochromic shift of $33 \mathrm{~nm}$.

\section{Electrochemistry}

Cyclic voltammetry of the zinc(II) and $\mathrm{BF}_{2}{ }^{+}$chelates was studied in dichloromethane solutions using ferrocene/ferricinium $\left(\mathrm{Fc} / \mathrm{Fc}^{+}\right)$as an internal reference. The electrochemical properties of the complexes are summarized in Table 2 with the voltammograms of the zinc(II) and $\mathrm{BF}_{2}{ }^{+}$chelates shown in Figure 6 and Figure 7, respectively. For all zinc(II) complexes, cyclic voltammograms reveal two reversible oxidations, while an irreversible oxidation occurs for all $\mathrm{BF}_{2}{ }^{+}$chelates. The first oxidation potentials $\left(E_{1 / 2}\right.$ ox. $)$ of the fluorinated zinc(II) chelates were higher than that of $\mathrm{Zn}(\mathrm{WS} 3)_{2}(0.50 \mathrm{~V})$ by at least $0.04 \mathrm{~V}$, with the highest value being $0.61 \mathrm{~V}$. The increased $E_{1 / 2}$ ox. values are consistent with the increased oxidative stability afforded by the addition of fluorine [13]. The second oxidation potential for all zinc(II) chelates, $0.77-0.79 \mathrm{~V}$, showed little change except in two cases: $\mathrm{Zn}(\mathrm{L} 4)_{2}$ and $\mathrm{Zn}(\mathrm{L} 2)_{2}$ had second oxidation potentials of $0.84 \mathrm{~V}$ and $0.73 \mathrm{~V}$, respectively. The differences between the first and second oxidation potential was $0.27 \mathrm{~V}$ for $\mathrm{Zn}(\mathrm{WS} 3)_{2}$, while it was $0.18 \mathrm{~V}$ and $0.19 \mathrm{~V}$ for $\mathrm{Zn}(\mathrm{L} 1)_{2}$ and $\mathrm{Zn}(\mathrm{L} 2)_{2}$, respectively. For both $\mathrm{Zn}(\mathrm{L} 3)_{2}$ and $\mathrm{Zn}(\mathrm{L} 4)_{2}$ the difference between oxidation potentials was $0.23 \mathrm{~V}$, a slight decrease from $\mathrm{Zn}(\mathrm{WS} 3)_{2}$ at $0.27 \mathrm{~V}$. All of the fluorinated zinc(II) complexes exhibit a rise of the first oxida-

Table 2: Electrochemical properties of zinc(II) and $\mathrm{BF}_{2}{ }^{+}$chelates in dichloromethane. All values reported are in $\mathrm{V} v \mathrm{sc} / \mathrm{Fc}^{+}$.

\begin{tabular}{lllll} 
& $E_{1 / 2}$ ox. & $E_{(\mathrm{p}, \mathrm{a})}$ & $E_{1 / 2 \text { red. }}$ & $E_{(\mathrm{p}, \mathrm{c})}$ \\
\hline $\mathrm{Zn}(\mathrm{WS} 3)_{2}$ & $0.50,0.77$ & $0.58,0.86$ & $-1.25,-1.47$ & $-1.33,-1.55$ \\
$\mathrm{BF}_{2}(\mathrm{WS} 3)$ & - & 1.08 & $-0.79,-1.59$ & $-0.95,-1.75$ \\
$\mathrm{Zn}(\mathrm{L} 1)_{2}$ & $0.60,0.78$ & $0.66,0.87$ & $-1.16,-1.39$ & $-1.11,-1.33$ \\
$\mathrm{BF}_{2}(\mathrm{~L} 1)$ & - & 0.96 & $-0.71,-1.48$ & $-0.67,-1.44$ \\
$\mathrm{Zn}(\mathrm{L} 2)_{2}$ & $0.54,0.73$ & $0.58,0.81$ & $-1.24,-1.45$ & $-1.19,-1.41$ \\
$\mathrm{BF}_{2}(\mathrm{~L} 2)$ & - & - & - & $-1.23,-1.44$ \\
$\mathrm{Zn}(\mathrm{L} 3)_{2}$ & $0.56,0.79$ & $0.61,0.86$ & $-0.72,-1.49$ & $-1.18,-1.39$ \\
$\mathrm{BF}_{2}(\mathrm{~L} 3)$ & - & 0.97 & $-1.15,-1.36$ & $-0.66,-1.44$ \\
$\mathrm{Zn}(\mathrm{L} 4)_{2}$ & $0.61,0.84$ & $0.66,0.88$ & $-0.69,-1.46$ & $-1.11,-1.32$ \\
$\mathrm{BF}_{2}(\mathrm{~L} 4)$ & - & 1.06 & & $-0.65,-1.42$
\end{tabular}




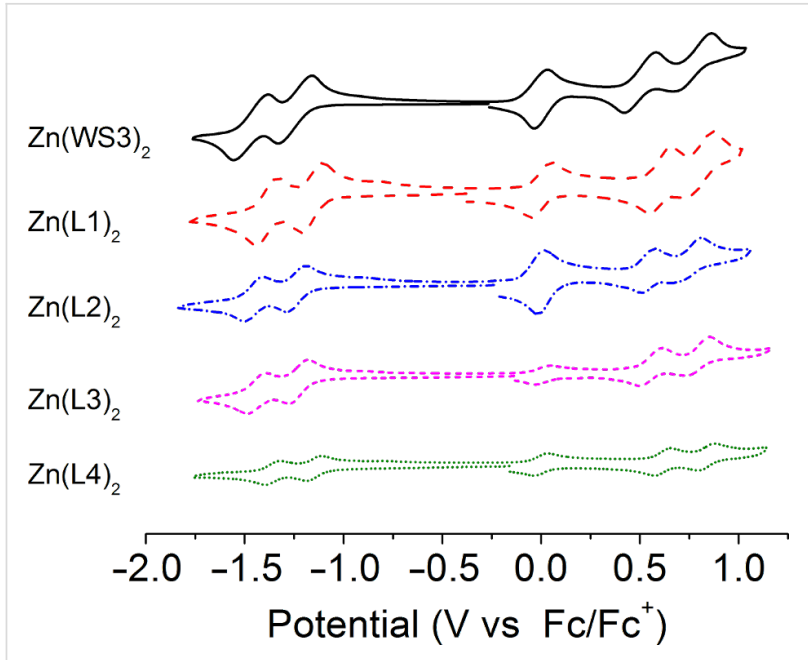

Figure 6: Cyclic voltamograms of zinc(II) chelates in $0.1 \mathrm{M} \mathrm{TBAPF}_{6}$ dichloromethane solution with $\mathrm{Fc} / \mathrm{Fc}^{+}$as an internal standard $\left(E_{1 / 2}\right.$ at $0.0 \mathrm{~V})$.

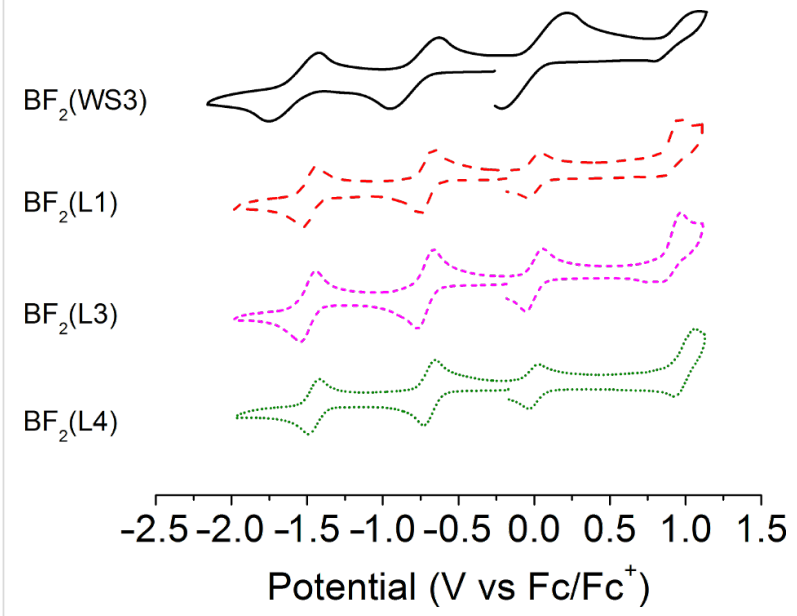

Figure 7: Cyclic voltamograms of $\mathrm{BF}_{2}{ }^{+}$chelates in $0.1 \mathrm{M} \mathrm{TBAPF}_{6}$ dichloromethane solution with $\mathrm{Fc} / \mathrm{Fc}^{+}$as an internal $\operatorname{standard}\left(E_{1 / 2}\right.$ at $0.0 \mathrm{~V})$.

tion potential as well as a decrease between the first and second oxidation potentials, compared to $\mathrm{Zn}(\mathrm{WS} 3)_{2}$.

Cyclic voltammograms of both the zinc(II) and $\mathrm{BF}_{2}{ }^{+}$complexes showed two reversible reduction potentials. The reduction potentials $\left(E_{1 / 2}\right.$ red. $)$ of $\mathrm{Zn}(\mathrm{L} 2)_{2}$ and $\mathrm{Zn}(\mathrm{L} 3)_{2}$ were similar to that of $\mathrm{Zn}(\mathrm{WS} 3)_{2}$, suggesting that the addition of one fluorine atom at the pyrrolic phenylacetylene or distal phenyl position does not stabilize the anion. On the other hand, there is significant increase of the reduction potentials going from $-1.25 \mathrm{~V}$ to $-1.16 \mathrm{~V}$ and $-1.15 \mathrm{~V}$ for $\mathrm{Zn}(\mathrm{WS} 3)_{2}, \mathrm{Zn}(\mathrm{L} 1)_{2}$ and $\mathrm{Zn}(\mathrm{L} 4)_{2}$, respectively. This suggests that fluorine stabilizes the anion when at the proximal position or when a $\mathrm{CF}_{3}$ group is installed at the pyrrolic phenylacetylene moiety. The difference between the first oxidation and first reduction potentials of all the zinc(II) complexes are similar, $1.75 \mathrm{~V}$ to $1.79 \mathrm{~V}$. This means that in the cases of $\mathrm{Zn}(\mathrm{L} 1)_{2}$ and $\mathrm{Zn}(\mathrm{L} 4)_{2}$, fluorine has a similar stabilizing effect on both the cation and anion.

The differences between the first and second reduction potentials of each compound were similar, indicating that fluorine influences both reductions equally. For the fluorinated $\mathrm{BF}_{2}{ }^{+}$ complexes, the first and second reduction potentials were slightly more positive than those of $\mathrm{BF}_{2}(\mathrm{WS} 3)$. The $E_{1 / 2}$ red. values ranged from $-0.79 \mathrm{~V}$ for $\mathrm{BF}_{2}(\mathrm{WS} 3)$ to $-0.69 \mathrm{~V}$ for $\mathrm{BF}_{2}(\mathrm{~L} 4)$. All the first reduction potentials of the fluorinated $\mathrm{BF}_{2}{ }^{+}$complexes were $-0.70 \mathrm{~V}$ with the difference between first and second $E_{1 / 2}$ values being $0.77 \mathrm{~V}$. Collectively, the fluorinemodified WS3 chelates showed higher oxidation potentials than those of unmodified chelates. The interpretation of electrochemical data shows that the addition of fluorine had the greatest effect on L1 and L4 chelates, while having minimal effects on the L2 and L3 chelates. The estimated HOMO and LUMO energy levels obtained from cyclic voltammetry are shown in Figure 8. The HOMO and LUMO of $\mathrm{Zn}(\mathrm{L} 1)_{2}$ and $\mathrm{Zn}(\mathrm{L} 4)_{2}$ approach those of PCBM.

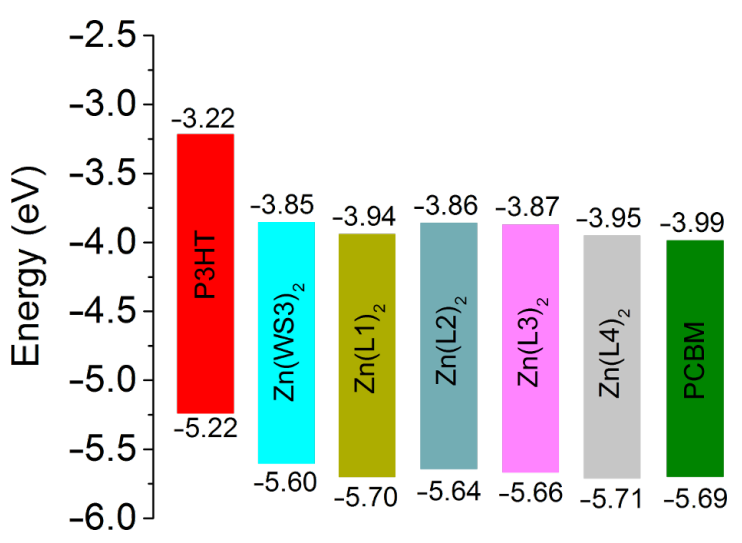

Figure 8: Estimated HOMO and LUMO energy levels obtained by cyclic voltammetry from the $E_{1 / 2}$ values in dichloromethane solution, using the value of $-5.1 \mathrm{eV}$ for $\mathrm{Fc} / \mathrm{Fc}^{+}$. The included $\mathrm{HOMO}$ and $\mathrm{LUMO}$ levels of P3HT films were estimated in our laboratory from the oxidation onset and the optical gap.

\section{Crystallography}

Single crystals of the zinc(II) chelates were grown in order to better understand the structure of the materials. Only $\mathrm{Zn}(\mathrm{L} 2)_{2}$ produced crystals suitable for analysis. Figure 9 shows the ORTEP drawing of $\mathrm{Zn}(\mathrm{L} 2)_{2}$ with $50 \%$ ellipsoids and a partial labeling scheme for clarity. The crystal structure confirms the identity of the complex and gives an idea of the interactions in 


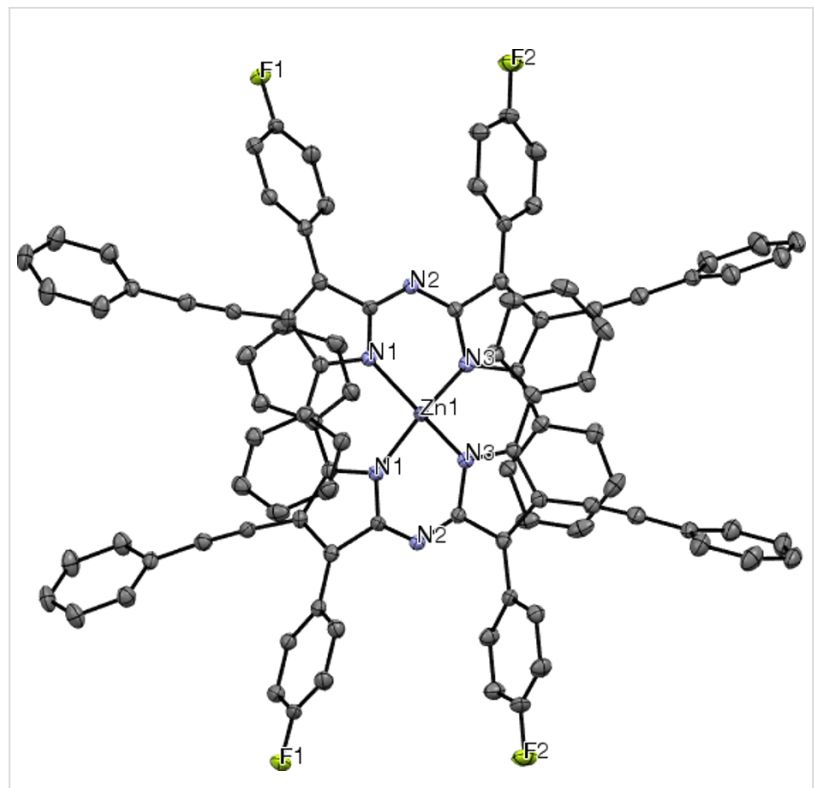

Figure 9: ORTEP drawing of $\mathrm{Zn}(\mathrm{L} 2)_{2}$ with ellipsoids drawn at the $50 \%$ probability level and a partial labeling scheme. The hydrogen atoms, and dichloromethane solvate were omitted for clarity.

the complex. Like $\mathrm{Zn}(\mathrm{ADP})_{2}$, the structure is distorted tetrahedral with favorable $\pi-\pi$ stacking distances between the proximal phenyl and pyrrole rings of the two separate ligands (Figure 10a and $10 \mathrm{~b}$ ). The distance between centroids is $3.56 \AA$ for $\mathrm{Zn}(\mathrm{L} 2)_{2}$, compared to $3.63 \AA$ for $\mathrm{Zn}(\mathrm{ADP})_{2}$ [38]. The shorter distance found for $\mathrm{Zn}(\mathrm{L} 2)_{2}$ suggests a stronger interaction between the proximal phenyl and pyrrole rings than in $\mathrm{Zn}(\mathrm{ADP})_{2}$. Unfortunately, it cannot be determined whether the addition of fluorine or phenylacetylene contributed to the shorter $\pi-\pi$ stacking distances without a crystal structure for $\mathrm{Zn}(\mathrm{WS} 3)_{2}$. Intermolecular favorable $\pi-\pi$ stacking distances are observed between the pyrrolic phenylacetylene arms of two chelates seen on the outside of the unit cell, as well as between the distal phenyl rings of two chelates. Due to the crowded packing and difficulty in obtaining a clear image to convey these observations, the authors invite the reader to observe the intermolecular packing on their own using the cif file provided as Supporting Information File 2. a)

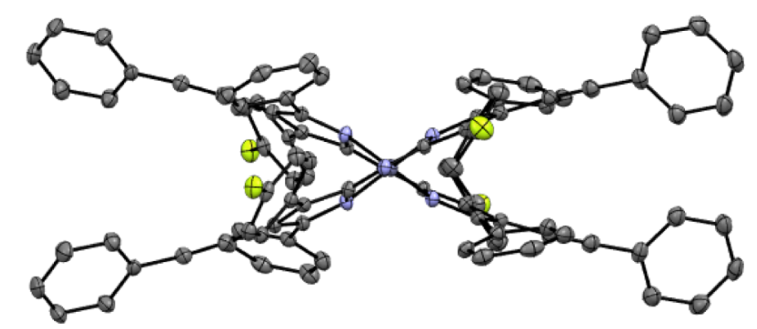

b)

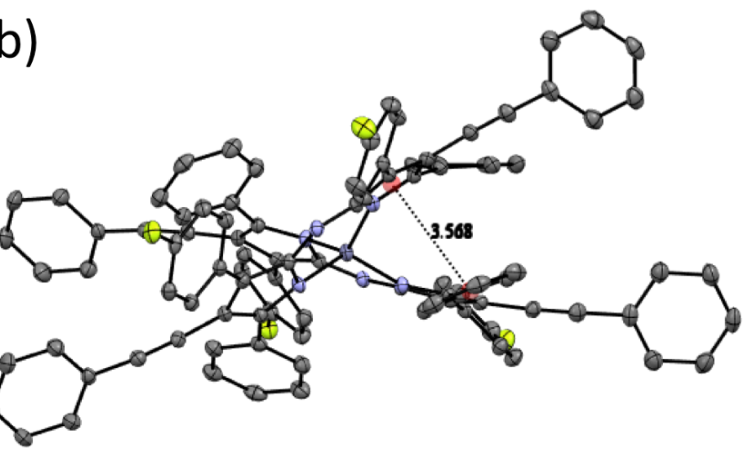

Figure 10: ORTEP drawing of $Z n(L 2)_{2}$ with ellipsoids drawn at the $50 \%$ probability level and a partial labeling scheme. The hydrogen atoms, and dichloromethane solvate were omitted for clarity. a) Shows the distorted tetrahedral shape; b) Shows the $\pi$-stacking between the proximal phenyl group of one ligand and a pyrrole ring of the opposite ligand.

\section{Preliminary results in OPVs}

To test the potential of the new fluorinated zinc(II) complexes as electron acceptor, we fabricated bulk heterojunction OPVs in the inverted configuration using $\mathrm{P} 3 \mathrm{HT}$ as the electron donor. The best results obtained so far are reported in Table 3. For comparison, we also included results for a typical P3HT:PCBM solar cell. First, we note that best PCEs for $\mathrm{Zn}(\mathrm{WS} 3)_{2}$ are lower than in our previous publication, $2.36 \%$ instead of $4.10 \%$ [10]. The main difference is that we now get lower $J_{\mathrm{sc}}, 5.2 \mathrm{~mA} / \mathrm{cm}^{2}$ instead of $9.1 \mathrm{~mA} / \mathrm{cm}^{2}$. While our previously reported results were reproducible at the time, we are no longer able to reproduce them with the new $\mathrm{Zn}(\mathrm{WS} 3)_{2}$ batches, even after extensive purification. We have therefore decided to report the results

Table 3: Preliminary results for OPVs using $\mathrm{P} 3 \mathrm{HT}$ as the donor.

\begin{tabular}{llllll} 
Acceptor & Donor:acceptor ratio & $V_{\text {OC }}[\mathrm{V}]$ & $J_{\text {SC }}\left[\mathrm{mA} / \mathrm{cm}^{2}\right]$ & FF [\%] & PCE [\%] \\
\hline Zn(WS3) 2 & $1: 0.7$ & 0.80 & 5.16 & 57 & 2.36 \\
Zn(L1) 2 & $1: 1$ & 0.68 & 5.08 & 59 & 1.55 \\
Zn(L2) 2 & $1: 0.7$ & 0.73 & 8.31 & 60 & 3.04 \\
Zn(L3) 2 & $1: 0.5$ & 0.73 & 8.54 & 66 & 3.74 \\
Zn(L4)2 & $1: 0.7$ & 0.59 & 9.29 & 61 & 3.26 \\
PCBM & $1: 0.8$ & 0.59 & 11.06 &
\end{tabular}


we now routinely obtain because they are obtained under similar conditions as the new results with the fluorinated compounds.

$\mathrm{Zn}(\mathrm{L} 2-\mathrm{L} 4)_{2}$ showed an increase in PCE compared to $\mathrm{Zn}(\mathrm{WS} 3)_{2}$, due to an increase in $J_{\mathrm{SC}}$. This points to a generally positive effect of fluorination on device performance. The current best performance of $3.74 \%$ was obtained with $\mathrm{Zn}(\mathrm{L} 3)_{2}$ with an open circuit voltage $\left(V_{\mathrm{oc}}\right)$ of $0.73 \mathrm{~V}$, a short-circuit current density $\left(J_{\mathrm{sc}}\right)$ of $8.54 \mathrm{~mA} / \mathrm{cm}^{2}$ and a fill factor $(\mathrm{FF})$ of $60 \%$. While maintaining similar $V_{\mathrm{oc}}$ and FF values, $\mathrm{Zn}(\mathrm{L} 2)_{2}$ had a lower PCE of $3.04 \%$ due to a decrease in $J_{\mathrm{sc}}$. With a PCE of $3.26 \%, \mathrm{Zn}(\mathrm{L} 4)_{2}$ showed the largest $J_{\mathrm{SC}}$ and $\mathrm{FF}$ but a lower $V_{\mathrm{oc}}$, consistent with its lower LUMO energy level than the other complexes. $\mathrm{Zn}(\mathrm{L} 4)_{2}$ shows the best potential to be paired with other electron donors of lower HOMO energy levels than P3HT. Compared to the P3HT:PCBM cell, the P3HT:Zn(L4) cell had a similar $V_{\mathrm{oc}}$, a higher FF, and a lower $J_{\mathrm{sc}}$. The lower $J_{\text {sc }}$ may be due to several factors, including purity, film thickness, morphology and charge recombination differences. Further studies are underway to better understand these results and will be reported separately.

\section{Conclusion}

In conclusion, four fluorinated WS3 derivatives were synthesized and the optical and electrochemical properties of their respective zinc(II) and $\mathrm{BF}_{2}{ }^{+}$chelates studied. It was found that the addition of fluorine into the $\mathrm{Zn}(\mathrm{L} 1)_{2}$ and $\mathrm{Zn}(\mathrm{L} 4)_{2}$ complexes raised the oxidation and reduction potentials. Fluorination was found to have little effect on the absorption spectra, both in solution and film. Preliminary results in OPVs suggest that fluorination is generally beneficial for device performance of zinc(II) azadipyrromethene-based acceptors. In particular, $\mathrm{Zn}(\mathrm{L} 4)_{2}$ is the best candidate to directly replace PCBM due to similar energy levels and good performance. More work is underway to better understand the mechanism for the enhancement, and will be published separately.

\section{Experimental Materials}

Chalcone (Acros), 4-fluorochalcone (TCI America), 4'-fluorochalcone (TCI America), 4,4'-difluorochalcone (TCI America), 1-ethynyl-4-fluorobenzene (Aldrich), 4-ethynyl- $\alpha, \alpha, \alpha$-trifluorotoluene (Aldrich), n-butyllithium solution (Aldrich), tributyltin chloride (Fisher), tributyl(phenylethynyl)tin (Aldrich), tetrakis(triphenylphosphine)palladium(0) (Aldrich), $n$-iodosuccinimide (abbreviated NIS, Aldrich) were used as received. All other reagents and solvents were used as received unless otherwise specified. Xylenes and tetrahydrofuran were distilled over sodium and benzophenone, degassed and stored under nitrogen. ADP, $\mathrm{ADPI}_{2}$,
$\mathrm{WS} 3, \mathrm{BF}_{2}(\mathrm{WS} 3)$, and $\mathrm{Zn}(\mathrm{WS} 3)_{2}$ were synthesized and purified according to literature procedures with minor modifications $[2,5,9,33,34]$. (4-Fluorophenylethynyl)tributyltin (for the synthesis of L3), and [4-(trifluoromethyl)phenyl](tributyltin)acetylene (for the synthesis of L4) were synthesized according to literature procedures with minor modifications and used without purification $[35,36]$.

\section{Methods}

${ }^{1} \mathrm{H},{ }^{19} \mathrm{~F}$, and ${ }^{13} \mathrm{C}$ NMR spectra were recorded using a $500 \mathrm{MHz}$ Bruker Ascend Avance III HDTM equipped with ProdigyTM ultra-high sensitivity Multinuclear Broadband CryoProbe or a Varian $400 \mathrm{MHz}$ spectrometer in parts-per-million with respect to tetramethylsilane. MALDI-TOF-MS samples were prepared from chloroform solutions in a terthiophene matrix and run on a Bruker Autoflex III MALDI-TOF-TOF-MS. UV-visible absorption and emission spectra were collected in HPLC grade chloroform on a UV-Cary 50 spectrometer and a Cary Eclipse fluorescence spectrometer, respectively. Solutions for films were prepared at $10 \mathrm{mg} / \mathrm{mL}$ concentration in HPLC grade chloroform. The solutions were filtered through a $0.45 \mu \mathrm{m}$ PTFE filter, then spun-cast at $400 \mathrm{rpm}$ for $60 \mathrm{~s}$. Elemental analyses $(\mathrm{C}, \mathrm{H}$, and $\mathrm{N})$ were performed under optimum combustion conditions by Robertson Microlit Laboratories. Thermal gravimetric analysis (TGA) was performed on a TA instrument Q500 thermogravimetric analyzer.

Cyclic voltammetry was performed at room temperature using an Auto-Lab-PGSTAT 302N, Exo Chemie potentiostat. Dichloromethane (DCM) was dried over calcium hydride and stored in a nitrogen glove box prior to use. The samples were prepared in a degassed $0.1 \mathrm{M}$ solution of tetra- $n$-butylammonium hexafluorophosphate $\left(\mathrm{TBAPF}_{6}\right)$ in DCM. Ferrocene/ ferrocenium was used as an internal standard and was purified prior to use by sublimation. A typical three-electrode configuration was used, with a glassy carbon electrode as the working electrode and two platinum wires used as the counter and pseudoreference electrodes.

Crystals suitable for X-ray diffraction analysis were obtained by the slow diffusion of methanol into a dichloromethane solution. The crystals obtained were dark blue-black in appearance. Single-crystal X-ray diffraction studies were carried out using a Rigaku Rapid II diffractometer using $\mathrm{Cu} \mathrm{K} \alpha(\lambda=1.54178 \AA)$ radiation monochromated using laterally graded multilayer (Goebel) mirror focusing optics. A single crystal was mounted on a Mitegen loop and cooled to $100 \mathrm{~K}$ for data collection. Unit cell parameters were measured and data were collected using the Rigaku CrystalClear software [39]. Data were reindexed and integrated using HKL3000, scaled, and corrected for absorption using Scalepack [40]. The space group was assigned and the 
structure was solved by direct methods using the SHELXTL suite of programs [41,42] and refined by full matrix least squares against $F^{2}$ with all reflections using Shelxl 2014 [43] using the graphical interface Shelxle [44]. H atoms attached to carbon atoms were positioned geometrically and constrained to ride on their parent atoms, with carbon hydrogen bond distances of $0.95 \AA$ for aromatic $\mathrm{C}-\mathrm{H}$ and $0.99 \AA$ for $\mathrm{CH}_{2}$ moieties, respectively. $U_{\text {iso }}(\mathrm{H})$ values were set to 1.2 times $U_{\text {eq }}(\mathrm{C})$. A dichloromethane molecule is disordered around a twofold axis.

\section{Synthesis}

L1-ADP: 4'-Fluorochalcone (2.01 g, $8.84 \mathrm{mmol})$ was dissolved in methanol $(25 \mathrm{~mL})$ in a round-bottom flask $(100 \mathrm{~mL})$ connected with a reflux condenser. Then nitromethane $(2.70 \mathrm{~g}$, $44.2 \mathrm{mmol}$ ) and diethylamine (3.23 g, $44.2 \mathrm{mmol}$ ) were added and refluxed for $24 \mathrm{~h}$. The mixture was cooled to room temperature and then chilled in an ice bath before adding a $1 \mathrm{M} \mathrm{HCl}$ solution dropwise $(100 \mathrm{~mL})$. The mixture was then extracted $3 \times$ with dichloromethane, dried with anhydrous magnesium sulfate, filtered and rotary evaporated to obtain a yellow oil. This oil was then dissolved in butanol $(100 \mathrm{~mL})$ in a $500 \mathrm{~mL}$ roundbottom flask. Ammonium acetate ( $24 \mathrm{~g}$ ) was added to the solution, stirred and heated to reflux. The solution became blue in about $30 \mathrm{~min}$. After continued refluxing for $24 \mathrm{~h}$, about $75 \%$ of the butanol was removed by rotary evaporation and the resulting dark blue slurry was filtered to collect the purplish blue solid product after washing with ethanol $(200 \mathrm{~mL})$ and vacuum dried overnight (0.484 g, 22.5\%). ${ }^{1} \mathrm{H}$ NMR (400 $\mathrm{MHz}, \mathrm{CDCl}_{3}$ ) $\delta 8.04-8.02(\mathrm{~d}, J=8 \mathrm{~Hz}, 4 \mathrm{H}), 7.91-7.88(\mathrm{t}, J=8 \mathrm{~Hz}, 4 \mathrm{H})$, 7.44-7.41 (t, $J=8 \mathrm{~Hz}, 4 \mathrm{H}), 7.38-7.35(\mathrm{t}, J=8 \mathrm{~Hz}, 2 \mathrm{H})$, $7.24-7.20(\mathrm{t}, J=8 \mathrm{~Hz}, 4 \mathrm{H}), 7.13(\mathrm{~s}, 2 \mathrm{H})) ;{ }^{19} \mathrm{~F}$ NMR $(470 \mathrm{MHz}$, $\left.\mathrm{CDCl}_{3}\right) \delta-92.35$.

L2-ADP: 4-Fluorochalcone (3.29 g, $13.26 \mathrm{mmol}$ ) was dissolved in methanol $(100 \mathrm{~mL})$ in a round-bottom flask $(100 \mathrm{~mL})$ connected with a reflux condenser. Then nitromethane $(4.32 \mathrm{~g}$, $70.8 \mathrm{mmol}$ ) and diethylamine $(5.66 \mathrm{~g}, 77.4 \mathrm{mmol})$ were added and heated to reflux for $24 \mathrm{~h}$. The mixture was cooled to room temperature and then chilled on an ice bath before adding $1 \mathrm{M} \mathrm{HCl}$ solution drop-wise $(100 \mathrm{~mL})$. The mixture was then extracted $3 \times$ with dichloromethane, dried with anhydrous magnesium sulfate, filtered and rotary evaporated to obtain a yellow oil. This oil was then dissolved in 1-butanol $(200 \mathrm{~mL})$ in a $500 \mathrm{~mL}$ round-bottom flask. Ammonium acetate (37.6 g) was added to the solution and stirred and heated to reflux. After continued refluxing for $24 \mathrm{~h}$, the 1-butanol was removed by rotary evaporation and the resulting solid was suspended in ethanol, filtered, and washed with ethanol $(100 \mathrm{~mL})$, and hexanes $(50 \mathrm{~mL})$. The solid was collected and vacuum dried overnight (0.919 g, 26\%). ${ }^{1} \mathrm{H}$ NMR (500 MHz, $\left.\mathrm{CDCl}_{3}\right) \delta 8.00$ (dd, $J=8 \mathrm{~Hz}, 2 \mathrm{H}), 7.96(\mathrm{~d}, J=8 \mathrm{~Hz}, 2 \mathrm{H}), 7.55(\mathrm{t}, J=7.5 \mathrm{~Hz}$, $4 \mathrm{H}), 7.48(\mathrm{t}, J=7.5 \mathrm{~Hz}, 2 \mathrm{H}), 7.16(\mathrm{~s}, 2 \mathrm{H}), 7.12(\mathrm{t}, J=7 \mathrm{~Hz}$, $4 \mathrm{H}) ;{ }^{19} \mathrm{~F} \mathrm{NMR}\left(470 \mathrm{MHz}, \mathrm{CDCl}_{3}\right) \delta-113.37$.

L1-ADPI 2 : A similar procedure was used as for $\mathrm{ADPI}_{2}$ $(0.550 \mathrm{~g}, 75 \%)$ [33]. ${ }^{19} \mathrm{~F}$ NMR $\left(470 \mathrm{MHz}, \mathrm{CDCl}_{3}\right) \delta-92.35$.

L2-ADPI 2 : A similar procedure was used as for $\mathrm{ADPI}_{2}$ $(0.998 \mathrm{~g}, 82 \%)$ [33]. MALDI-TOF-MS $\mathrm{m} / \mathrm{z}$ : calcd for $\mathrm{C}_{32} \mathrm{H}_{19} \mathrm{~F}_{2} \mathrm{I}_{2} \mathrm{~N}_{3}$, 736.96; found, 735.85.

L1: Tributyl(phenylethynyl)tin $(318 \mathrm{mg}, 0.813 \mathrm{mmol})$ and L1-ADPI 2 (200 mg, $0.271 \mathrm{mmol}$ ) was taken into a Schlenk flask $(50 \mathrm{~mL})$ which was evacuated and refilled with $\mathrm{N}_{2}$ three times. Dry chlorobenzene $(15 \mathrm{~mL})$ was added to the flask using a syringe and stirred and $\mathrm{N}_{2}$ was bubbled through for $10 \mathrm{~min}$. Then $\mathrm{Pd}\left(\mathrm{PPh}_{3}\right)_{4}(0.094 \mathrm{~g}, 10 \mathrm{mmol} \%)$ was added inside a glove box. The mixture was heated at $90{ }^{\circ} \mathrm{C}$ for $48 \mathrm{~h}$ under $\mathrm{N}_{2}$. After cooling to room temperature, the mixture was dissolved in dichloromethane $(500 \mathrm{~mL})$ and passed through a Celite plug. The filtrate was concentrated using rotary evaporation of dichloromethane and poured into methanol $(300 \mathrm{~mL})$ to precipitate. The precipitate was filtered and washed with methanol and ether. After drying under vacuum overnight, the product was obtained as a dark blue solid $(0.145 \mathrm{~g}, 78 \%)$. ${ }^{19} \mathrm{~F}$ NMR $\left(470 \mathrm{MHz}, \mathrm{CDCl}_{3}, \delta\right)-92.35$.

L2: Tributyl(phenylethynyl)tin $(0.928 \mathrm{~g}, 2.373 \mathrm{mmol})$ and

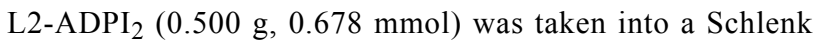
flask (100 mL), which was evacuated and refilled with $\mathrm{N}_{2}$ three times. Distilled xylenes $(50 \mathrm{~mL})$ were added to the flask using a syringe and placed under slight vacuum. Then $\operatorname{Pd}\left(\mathrm{PPh}_{3}\right)_{4}$ $(0.110 \mathrm{~g}, 14 \mathrm{mmol} \%)$ was added inside a glove box. The mixture was heated at $125{ }^{\circ} \mathrm{C}$ for $24 \mathrm{~h}$ under $\mathrm{N}_{2}$. After cooling to room temperature, the mixture was concentrated to a solid using rotary evaporation. The mixture was then cooled on dry ice and triturated with cold methanol $(125 \mathrm{~mL})$, filtered, and then washed with cold diethyl ether $(125 \mathrm{~mL})$. After drying under vacuum overnight, the product was obtained as a dark blue solid (0.441 g, 94\%). MALDI-TOF-MS $m / z$ : calcd. for $\mathrm{C}_{48} \mathrm{H}_{29} \mathrm{~F}_{2} \mathrm{~N}_{3}$, 685.23; found, 684.06 .

L3: (4-Fluorophenylethynyl)tributyltin (0.612 g, $1.495 \mathrm{mmol}$ ) and $\mathrm{ADPI}_{2}(0.300 \mathrm{~g}, 0.427 \mathrm{mmol})$ was taken into a Schlenk flask $(100 \mathrm{~mL})$, which was evacuated and refilled with $\mathrm{N}_{2}$ three times. Distilled xylenes $(50 \mathrm{~mL})$ were added to the flask using a syringe and placed under slight vacuum. Then $\mathrm{Pd}\left(\mathrm{PPh}_{3}\right)_{4}$ $(0.049 \mathrm{~g}, 10 \mathrm{mmol} \%)$ was added inside a glove box. The mixture was heated at $125^{\circ} \mathrm{C}$ for $48 \mathrm{~h}$ under $\mathrm{N}_{2}$. After $48 \mathrm{~h}$, additional (4-fluorophenylethynyl)tributyltin (0.612 g, $1.495 \mathrm{mmol})$ and $\mathrm{Pd}\left(\mathrm{PPh}_{3}\right)_{4}(0.049 \mathrm{~g}, 10 \mathrm{mmol} \%)$ were added in one shot. 
The reaction mixture was allowed to react an additional $48 \mathrm{~h}$ at $125^{\circ} \mathrm{C}$ under $\mathrm{N}_{2}$. After cooling to room temperature, the mixture was concentrated using rotary evaporation. The mixture was then cooled on dry ice and triturated with cold methanol $(125 \mathrm{~mL})$, filtered, and then washed with cold diethyl ether $(125 \mathrm{~mL})$. After drying under vacuum overnight, the product was obtained as a dark blue solid (0.206 g, 70\%). MALDI-TOF-MS m/z: calcd. for $\mathrm{C}_{48} \mathrm{H}_{29} \mathrm{~F}_{2} \mathrm{~N}_{3}, 685.23$; found, 684.39 .

L4: [4-(Trifluoromethyl)phenyl](tributyltin)acetylene (0.686 g, $1.495 \mathrm{mmol})$ and $\mathrm{ADPI}_{2}(0.313 \mathrm{~g}, 0.445 \mathrm{mmol})$ was taken into a Schlenk flask $(100 \mathrm{~mL})$, which was evacuated and refilled with $\mathrm{N}_{2}$ three times. Distilled xylenes $(50 \mathrm{~mL})$ were added to the flask using a syringe and placed under slight vacuum. Then $\mathrm{Pd}\left(\mathrm{PPh}_{3}\right)_{4}(0.049 \mathrm{~g}, 10 \mathrm{mmol} \%)$ was added inside a glove box. The mixture was heated at $125{ }^{\circ} \mathrm{C}$ for $48 \mathrm{~h}$ under $\mathrm{N}_{2}$. After $48 \mathrm{~h}$, additional [4-(trifluoromethyl)phenyl](tributyltin)acetylene $(0.686 \mathrm{~g}, 1.495 \mathrm{mmol})$ and $\mathrm{Pd}\left(\mathrm{PPh}_{3}\right)_{4}(0.049 \mathrm{~g}$, $10 \mathrm{mmol} \%$ ) were added in one shot. The reaction mixture was allowed to react an additional $48 \mathrm{~h}$ at $125^{\circ} \mathrm{C}$ under $\mathrm{N}_{2}$. After cooling to room temperature, the mixture was concentrated using rotary evaporation. The mixture was then cooled on dry ice and triturated with cold methanol $(125 \mathrm{~mL})$, filtered, and then washed with cold diethyl ether $(125 \mathrm{~mL})$. After drying under vacuum overnight, the product was obtained as a dark blue solid (0.301 g, 89\%). MALDI-TOF-MS $m / z$ : calcd. for $\mathrm{C}_{50} \mathrm{H}_{29} \mathrm{~F}_{6} \mathrm{~N}_{3}, 785.79$; found, 783.94

$\mathbf{B F}_{2}(\mathbf{L 1})$ : It was synthesized using a similar procedure as for $\mathrm{BF}_{2}$ (WS3)[34]. L1 (0.042 g, $\left.0.1 \mathrm{mmol}\right)$ was added to a dry round bottom flask $(100 \mathrm{~mL})$, sealed, flushed with nitrogen and charged with anhydrous DCM $(25 \mathrm{~mL})$. Diisopropylethylamine $(0.2 \mathrm{~mL})$ was added via syringe followed immediately by the addition of trifluoroboron etherate $(0.4 \mathrm{~mL})$ by syringe. The reaction mixture was stirred for $16 \mathrm{~h}$ at room temperature under $\mathrm{N}_{2}$. The solution was washed with distilled water $(\approx 50 \mathrm{~mL} \times 3)$ and dried over anhydrous $\mathrm{MgSO}_{4}$ prior to concentration by rotary evaporation. The crude solid was further purified by column chromatography on silica gel using a 1:1 ratio of DCM/ hexanes $(\mathrm{v} / \mathrm{v})$. The final pure product was obtained as a dark blue solid after removal of solvents $(0.047 \mathrm{~g}, 74 \%){ }^{1} \mathrm{H}$ NMR (500 MHz, $\left.\mathrm{CD}_{2} \mathrm{Cl}_{2}, \delta\right) 8.26-8.24(\mathrm{~d}, J=10 \mathrm{~Hz}, 4 \mathrm{H}), 8.08-8.05$ (t, $J=10 \mathrm{~Hz}, 4 \mathrm{H}), 7.56-7.49(\mathrm{~m}, 6 \mathrm{H}), 7.34(\mathrm{~s}, 10 \mathrm{H}), 7.28-7.24$ $(\mathrm{t}, J=10 \mathrm{~Hz}, 5 \mathrm{H}) ;{ }^{19} \mathrm{~F} \mathrm{NMR}\left(470 \mathrm{MHz}, \mathrm{CDCl}_{3}, \delta\right)$ -108.30-108.40 (m), -131-131.5 (dd); MALDI-TOF-MS $m / z$ : calcd. for $\mathrm{C}_{48} \mathrm{H}_{28} \mathrm{BF}_{4} \mathrm{~N}_{3}$, 733.23; found, 731.86; anal. calcd for: C, 78.59; H, 3.85; N, 5.73; found: C, 78.56; H, 4.00; N, 5.45.

$\mathbf{B F}_{\mathbf{2}}(\mathbf{L 3})$ : It was synthesized using a similar procedure as for $\mathrm{BF}_{2}(\mathrm{~L} 1)(0.039 \mathrm{~g}, 73 \%) .{ }^{1} \mathrm{H} \mathrm{NMR}\left(500 \mathrm{MHz}, \mathrm{CDCl}_{3}\right) \delta 8.23$ (m, 4H), $8.01(\mathrm{~m}, 4 \mathrm{H}), 7.51(\mathrm{~m}, 13 \mathrm{H}), 7.28(\mathrm{~m}, 5 \mathrm{H}), 7.00(\mathrm{t}, J=$ $7 \mathrm{~Hz}, 4 \mathrm{H}) ;{ }^{19} \mathrm{~F}$ NMR $\left(470 \mathrm{MHz}, \mathrm{CDCl}_{3}\right) \delta-109.30-110.40$ (m), -131-131.1 (dd); MALDI-TOF-MS m/z: calcd. for $\mathrm{C}_{48} \mathrm{H}_{28} \mathrm{BF}_{4} \mathrm{~N}_{3}$, 733.23; found, 731.94; anal. calcd for: $\mathrm{C}, 78.59$; H, 3.85; N, 5.73; found: C, 78.41; H, 3.62; N, 5.98.

$\mathbf{B F}_{\mathbf{2}}(\mathbf{L 4})$ : It was synthesized using a similar procedure than that of $\mathrm{BF}_{2}(\mathrm{~L} 1)(0.064 \mathrm{~g}, 59 \%) .{ }^{1} \mathrm{H} \mathrm{NMR}\left(500 \mathrm{MHz}, \mathrm{CDCl}_{3}\right) \delta 8.22$ $(\mathrm{m}, 4 \mathrm{H}), 8.03(\mathrm{~m}, 4 \mathrm{H}), 7.54(\mathrm{~m}, 14 \mathrm{H}), 7.4(\mathrm{~m}, 4 \mathrm{H}) ;{ }^{19} \mathrm{~F} \mathrm{NMR}$ $\left(470 \mathrm{MHz}, \mathrm{CDCl}_{3}, \delta\right)-62.9$ (s), $-130-131.1$ (dd); MALDI-TOF-MS $\mathrm{m} / \mathrm{z}$ : calcd. for $\mathrm{C}_{50} \mathrm{H}_{28} \mathrm{BF}_{8} \mathrm{~N}_{3}, 833.22$; found, 831.90; anal. calcd for: C, 72.04; H, 3.39; N, 5.04; found: C, 74.24; H, 3.25; N, 5.30.

$\mathbf{Z n ( L 1 )})_{2}$ : In a $100 \mathrm{~mL}$ three-necked flask equipped with a reflux condenser, L1 (100 mg, $0.146 \mathrm{mmol})$ was dissolved in anhydrous tetrahydrofuran $(10 \mathrm{~mL})$ under $\mathrm{N}_{2}$. To this dark blue solution, anhydrous $\mathrm{NaH}(4.00 \mathrm{mg}, 0.161 \mathrm{mmol})$ was added and the mixture was heated to $60{ }^{\circ} \mathrm{C}$. The solution turned to bright blue. After $24 \mathrm{~h}$ of heating, anhydrous $\mathrm{ZnCl}_{2}(11.5 \mathrm{mg}$, $0.084 \mathrm{mmol}$ ) was added and heating was continued for another $24 \mathrm{~h}$. The mixture turned back to dark blue. Then the mixture was cooled to room temperature and dissolved in dichloromethane $(200 \mathrm{~mL})$. This solution was then passed through a Celite plug and the filtrate was collected. The crude product was obtained by rotary evaporation of dichloromethane, and purified by flash chromatography using a dichloromethane/ hexane mixture as the eluent (starting with $80 \%$ hexane and gradually decreasing the amount to $60 \%$ ). The final pure product was obtained as a dark blue solid after removal of solvents (0.091 g, 87\%). ${ }^{1} \mathrm{H}$ NMR (400 MHz, $\left.\mathrm{CD}_{2} \mathrm{Cl}_{2}\right) \delta$ 7.98-7.97 (d, $J$ $=4 \mathrm{~Hz}, 8 \mathrm{H}), 7.84-7.81(\mathrm{dd}, J=8 \mathrm{~Hz}, J=4 \mathrm{~Hz}, 8 \mathrm{H}), 7.54-7.46$ (m, 12H), 7.39-7.36 (m, 8H), 7.35-7.32 (m, 12H), 7.04-7.00 (t, $J=8 \mathrm{~Hz}, 8 \mathrm{H}) ;{ }^{19} \mathrm{~F}$ NMR $\left(470 \mathrm{MHz}, \mathrm{CDCl}_{3}\right) \delta-110.36(\mathrm{~s})$; MALDI-TOF-MS $m / z$ : calcd for $\mathrm{C}_{96} \mathrm{H}_{56} \mathrm{~F}_{4} \mathrm{~N}_{6} \mathrm{Zn}, 1433.38$; found, 1431.36. anal. calcd for: $\mathrm{C}, 80.36 ; \mathrm{H}, 3.93 ; \mathrm{N}, 5.86$; found: C, 80.58; H, 4.08; N, 5.89.

Zn(L2) 2: In a $100 \mathrm{~mL}$ three-necked flask L2 (0.229 g, $0.334 \mathrm{mmol}$ ) was dissolved in anhydrous tetrahydrofuran $\left(20 \mathrm{~mL}\right.$ ) under $\mathrm{N}_{2}$. To this dark blue solution, anhydrous $\mathrm{NaH}$ $(0.008 \mathrm{~g}, 0.401 \mathrm{mmol})$ was added and the mixture was heated to $60{ }^{\circ} \mathrm{C}$. The solution turned bright blue. After $16 \mathrm{~h}$ of heating, anhydrous $\mathrm{ZnCl}_{2}$ (0.023 g, $\left.0.168 \mathrm{mmol}\right)$ was added and heating was continued for another $16 \mathrm{~h}$. The crude product was obtained by rotary evaporation of dichloromethane and purified by flash chromatography using a dichloromethane/hexane mixture as the eluent (started with $80 \%$ hexane and gradually decreasing to $60 \%$ ). The final pure product was obtained as a dark blue solid after removal of solvents $(0.167 \mathrm{~g}, 70 \%) .{ }^{1} \mathrm{H}$ NMR (400 MHz, $\left.\mathrm{CD}_{2} \mathrm{Cl}_{2}, \delta\right) 7.94$ (dd, $\left.J=8 \mathrm{~Hz}, 8 \mathrm{H}\right), 7.78(\mathrm{~m}, 8 \mathrm{H})$, 
$7.36(\mathrm{~m}, 8 \mathrm{H}), 7.30(\mathrm{~m}, 12 \mathrm{H}), 7.22(\mathrm{~m}, 12 \mathrm{H}), 7.17(\mathrm{t}, J=7 \mathrm{~Hz}$, $8 \mathrm{H}) ;{ }^{19} \mathrm{~F} \mathrm{NMR}\left(470 \mathrm{MHz}, \mathrm{CDCl}_{3}\right) \delta-112.77$ (s). MALDI-TOF-MS $m / z$ : calcd for $\mathrm{C}_{96} \mathrm{H}_{56} \mathrm{~F}_{4} \mathrm{~N}_{6} \mathrm{Zn}, 1433.38$; found, 1432.46; anal. calcd for: $\mathrm{C}, 80.36 ; \mathrm{H}, 3.93 ; \mathrm{N}, 5.86$; found: C, 80.19; H, 4.04; N, 5.78.

Zn(L3) 2: In a $100 \mathrm{~mL}$ three-necked flask L3 (0.166 g, $0.242 \mathrm{mmol}$ ) was dissolved in anhydrous tetrahydrofuran (15 mL) under $\mathrm{N}_{2}$. To this dark blue solution, anhydrous $\mathrm{NaH}$ $(0.006 \mathrm{~g}, 0.266 \mathrm{mmol})$ was added and the mixture was heated to $60{ }^{\circ} \mathrm{C}$. The solution became bright blue. After $16 \mathrm{~h}$ of heating, anhydrous $\mathrm{ZnCl}_{2}(0.016 \mathrm{~g}, 0.121 \mathrm{mmol})$ was added and heating was continued for another $16 \mathrm{~h}$. The crude product was obtained by rotary evaporation of dichloromethane and purified by flash chromatography using a dichloromethane/hexane mixture as the eluent (starting with $80 \%$ hexane and gradually decreasing to $60 \%$ ). The final pure product was obtained as a dark blue solid after removal of solvents $(0.119 \mathrm{~g}, 69 \%) .{ }^{1} \mathrm{H}$ NMR $\left(400 \mathrm{MHz}, \mathrm{CD}_{2} \mathrm{Cl}_{2}, \delta\right) 7.94(\mathrm{~d}, J=8 \mathrm{~Hz}, 8 \mathrm{H}), 7.78(\mathrm{~d}, J=8 \mathrm{~Hz}$, $8 \mathrm{H}), 7.48(\mathrm{~m}, 12 \mathrm{H}), 7.34(\mathrm{~m}, 8 \mathrm{H}), 7.01(\mathrm{t}, J=7 \mathrm{~Hz}, 8 \mathrm{H})$; ${ }^{19} \mathrm{~F} \mathrm{NMR}\left(470 \mathrm{MHz}, \mathrm{CDCl}_{3}\right) \delta-111.77$ (s). MALDI-TOF-MS $m / z$ : calcd for $\mathrm{C}_{96} \mathrm{H}_{56} \mathrm{~F}_{4} \mathrm{~N}_{6} \mathrm{Zn}, 1433.38$; found, 1432.80; anal. calcd for: C, 80.36; H, 3.93; N, 5.86; found: C, 80.13; H, 4.09; N, 5.69 .

Zn(L4)2: In a $100 \mathrm{~mL}$ three-necked flask L4 (0.346 g, $0.440 \mathrm{mmol}$ ) was dissolved in anhydrous tetrahydrofuran $(20 \mathrm{~mL})$ under $\mathrm{N}_{2}$. To this dark blue solution, anhydrous $\mathrm{NaH}$ $(0.012 \mathrm{~g}, 0.484 \mathrm{mmol})$ was added and the mixture was heated to $60{ }^{\circ} \mathrm{C}$. The solution turned into a bright blue solution. After $16 \mathrm{~h}$ of heating, anhydrous $\mathrm{ZnCl}_{2}(0.030 \mathrm{~g}, 0.220 \mathrm{mmol})$ was added and heating was continued for another $16 \mathrm{~h}$. The crude product was obtained by rotary evaporation of dichloromethane and purified by flash chromatography using dichloromethane/ hexane mixture as the eluent (started with $80 \%$ hexane and gradually decreasing to $60 \%$ ). The final pure product was obtained as a dark blue solid after removal of solvents $(0.195 \mathrm{~g}$, 54\%). ${ }^{1} \mathrm{H}$ NMR (400 MHz, $\left.\mathrm{CD}_{2} \mathrm{Cl}_{2}\right) \delta 7.90$ (d, $\left.J=8 \mathrm{~Hz}, 8 \mathrm{H}\right)$, $7.76(\mathrm{~m}, 8 \mathrm{H}), 7.63(\mathrm{~d}, J=7 \mathrm{~Hz}, 8 \mathrm{H}), 7.46-7.44(\mathrm{dd}, J=8 \mathrm{~Hz}$, $20 \mathrm{H}) ;{ }^{19} \mathrm{~F} \mathrm{NMR}\left(470 \mathrm{MHz}, \mathrm{CDCl}_{3}\right) \delta-63.07$ (s). MALDI-TOF-MS $m / z$ : calcd for $\mathrm{C}_{96} \mathrm{H}_{56} \mathrm{~F}_{4} \mathrm{~N}_{6} \mathrm{Zn}, 1633.37$; found, 1629.75; anal. calcd for: C, 73.46; H, 3.45; N, 5.14; found: C, 73.42; H, 3.69; N, 5.06.

\section{Organic solar cells}

Photovoltaic properties were studied using the inverted configuration: ITO/ZnO/P3HT:Acceptor/ $/ \mathrm{MoO}_{3} / \mathrm{Ag}$. ITO-coated glass $(R=15 \Omega / \mathrm{sq})$ substrates were cleaned stepwise in each of the following under ultra-sonication for 15 minutes: detergent, deionized water, acetone, and isopropanol. From a $0.25 \mathrm{M} \mathrm{ZnO}$ precursor solution, the $\mathrm{ZnO}$ layer was spun coat. For all of the devices fabricated, the total concentration of the active layer was $20 \mathrm{mg} / \mathrm{mL}$ with varying donor-to-acceptor ratios (see Table 3). While in an oxygen and moisture-free environment, the photoactive layer was spun coat at $1000 \mathrm{rpm}$ for $40 \mathrm{~s}$ and $2000 \mathrm{rpm}$ for $2 \mathrm{~s}$. The substrates were annealed at $120^{\circ} \mathrm{C}$ for 30 min prior to top electrode deposition. The P3HT:PCBM devices had a total concentration of $40 \mathrm{mg} / \mathrm{mL}, 1: 0.8$ donor-to-acceptor ratio, were spun coat at $800 \mathrm{rpm}$ for $40 \mathrm{~s}$ and $2000 \mathrm{rpm}$ for $2 \mathrm{~s}$ and annealed at $120^{\circ} \mathrm{C}$ for $15 \mathrm{~min}$. Molybdenum oxide (10 nm) and silver $(80 \mathrm{~nm})$ were thermally evaporated in sequence under a vacuum pressure of $\approx 3 \times 10^{-6}$ Torr using an Angstrom Engineering Evovac thermal evaporator. The devices were characterized using a Oriel Sol2A solar simulator and a Keithley 2400 SourceMeter. The active area of each solar cell is $0.20 \mathrm{~cm}^{2}$.

\section{Supporting Information}

\section{Supporting Information File 1 \\ NMR and MS data. \\ [http://www.beilstein-journals.org/bjoc/content/ \\ supplementary/1860-5397-12-182-S1.pdf]}

\section{Supporting Information File 2}

Crystal structure of $\mathrm{Zn}(\mathrm{L} 2)_{2}$.

[http://www.beilstein-journals.org/bjoc/content/

supplementary/1860-5397-12-182-S2.cif]

\section{Acknowledgements}

We gratefully acknowledge the National Science Foundation (CHEM 1148652) for funding this project. We thank Dr. Ina Martin and the Materials for Opto/Electronic Research and Education (MORE) Center at CWRU for help related to devices. This material is based upon work supported by the National Science Foundation under Grant MRI-28.5 0821515 (for the purchase of the MALDI-TOF-TOF).

\section{References}

1. Loudet, A.; Burgess, K. Chem. Rev. 2007, 107, 4891-4932. doi:10.1021/cr078381n

2. Palma, A.; Gallagher, J. F.; Müller-Bunz, H.; Wolowska, J.; Mclnnes, E. J. L.; O'Shea, D. F. Dalton Trans. 2009, 273-279. doi:10.1039/B811764K

3. Partyka, D. V.; Deligonul, N.; Washington, M. P.; Gray, T. G. Organometallics 2009, 28, 5837-5840. doi:10.1021/om900552e

4. Ge, Y.; O'Shea, D. F. Chem. Soc. Rev. 2016, 45, 3846-3864. doi:10.1039/C6CS00200E

5. Gorman, A.; Killoran, J.; O'Shea, C.; Kenna, T.; Gallagher, W. M.; O'Shea, D. F. J. Am. Chem. Soc. 2004, 126, 10619-10631. doi:10.1021/ja047649e 
6. Byrne, A. T.; O'Connor, A. E.; Hall, M.; Murtagh, J.; O'Neill, K.; Curran, K. M.; Mongrain, K.; Rousseau, J. A.; Lecomte, R.; McGee, S.; Callanan, J. J.; O'Shea, D. F.; Gallagher, W. M. Br. J. Cancer 2009, 101, 1565-1573. doi:10.1038/sj.bjc.6605247

7. Killoran, J.; Allen, L.; Gallagher, J. F.; Gallagher, W. M.; O'Shea, D. F. Chem. Commun. 2002, 1862-1863. doi:10.1039/B204317C

8. O'Connor, A. E.; Mc Gee, M. M.; Likar, Y.; Ponomarev, V.; Callanan, J. J.; O'Shea D, F.; Byrne, A. T.; Gallagher, W. M. Int. J. Cancer 2012, 130, 705-715. doi:10.1002/ijc.26073

9. Senevirathna, W.; Liao, J.-y.; Mao, Z.; Gu, J.; Porter, M.; Wang, C.; Fernando, R.; Sauvé, G. J. Mater. Chem. A 2015, 3, 4203-4214. doi:10.1039/C4TA05765A

10. Mao, Z.; Senevirathna, W.; Liao, J.-Y.; Gu, J.; Kesava, S. V.; Guo, C.; Gomez, E. D.; Sauvé, G. Adv. Mater. 2014, 26, 6290-6294. doi:10.1002/adma.201400647

11. Sauvé, G.; Fernando, R. J. Phys. Chem. Lett. 2015, 6, 3770-3780. doi:10.1021/acs.jpclett.5b01471

12. Senevirathna, W.; Daddario, C. M.; Sauvé, G. J. Phys. Chem. Lett. 2014, 5, 935-941. doi:10.1021/jz402735c

13. Babudri, F.; Farinola, G. M.; Naso, F.; Ragni, R. Chem. Commun. 2007, 1003-1022. doi:10.1039/B611336B

14. Leroux, F.; Jeschke, P.; Schlosser, M. Chem. Rev. 2005, 105, 827-856. doi:10.1021/cr040075b

15. Pagliaro, M.; Ciriminna, R. J. Mater. Chem. 2005, 15, 4981-4991. doi:10.1039/b507583c

16. Chambers, R. D. Fluorine in Organic Chemistry; CRC Press: Boca Raton, FL, U.S.A., 2004; p 406. doi:10.1002/9781444305371

17. Price, S. C.; Stuart, A. C.; Yang, L.; Zhou, H.; You, W. J. Am. Chem. Soc. 2011, 133, 4625-4631. doi:10.1021/ja1112595

18. Stuart, A. C.; Tumbleston, J. R.; Zhou, H.; Li, W.; Liu, S.; Ade, H.; You, W. J. Am. Chem. Soc. 2013, 135, 1806-1815. doi:10.1021/ja309289u

19. Yang, P.; Yuan, M.; Zeigler, D. F.; Watkins, S. E.; Lee, J. A.; Luscombe, C. K. J. Mater. Chem. C 2014, 2, 3278-3284. doi:10.1039/C3TC32087A

20. Liang, Y.; Xu, Z.; Xia, J.; Tsai, S.-T.; Wu, Y.; Li, G.; Ray, C.; Yu, L. Adv. Mater. 2010, 22, E135-E138. doi:10.1002/adma.200903528

21. Zhou, H.; Yang, L.; Stuart, A. C.; Price, S. C.; Liu, S.; You, W. Angew. Chem., Int. Ed. 2011, 50, 2995-2998. doi:10.1002/anie.201005451

22. Reichenbächer, K.; Süss, H. I.; Hulliger, J. Chem. Soc. Rev. 2005, 34, 22-30.

23. Günes, S.; Neugebauer, H.; Sariciftci, N. S. Chem. Rev. 2007, 107, 1324-1338. doi:10.1021/cr050149z

24. Heremans, P.; Cheyns, D.; Rand, B. P. Acc. Chem. Res. 2009, 42, 1740-1747. doi:10.1021/ar9000923

25. Love, J. A.; Nagao, I.; Huang, Y.; Kuik, M.; Gupta, V.; Takacs, C. J.; Coughlin, J. E.; Qi, L.; van der Poll, T. S.; Kramer, E. J.; Heeger, A. J.; Nguyen, T.-Q.; Bazan, G. C. J. Am. Chem. Soc. 2014, 136, 3597-3606. doi:10.1021/ja412473p

26. Liu, Y.; Zhao, J.; Li, Z.; Mu, C.; Ma, W.; Hu, H.; Jiang, K.; Lin, H.; Ade, H.; Yan, H. Nat. Commun. 2014, 5, 5293. doi:10.1038/ncomms6293

27. Albrecht, S.; Janietz, S.; Schindler, W.; Frisch, J.; Kurpiers, J.; Kniepert, J.; Inal, S.; Pingel, P.; Fostiropoulos, K.; Koch, N.; Neher, D. J. Am. Chem. Soc. 2012, 134, 14932-14944. doi:10.1021/ja305039j

28. Carsten, B.; Szarko, J. M.; Son, H. J.; Wang, W.; Lu, L.; He, F.; Rolczynski, B. S.; Lou, S. J.; Chen, L. X.; Yu, L. J. Am. Chem. Soc. 2011, 133, 20468-20475. doi:10.1021/ja208642b
29. Yang, L.; Tumbleston, J. R.; Zhou, H.; Ade, H.; You, W. Energy Environ. Sci. 2013, 6, 316-326. doi:10.1039/C2EE23235A

30. Katz, H. E.; Lovinger, A. J.; Johnson, J.; Kloc, C.; Siegrist, T.; Li, W.; Lin, Y.-Y.; Dodabalapur, A. Nature 2000, 404, 478-481. doi:10.1038/35006603

31. Sonar, P.; Ng, G.-M.; Lin, T. T.; Dodabalapur, A.; Chen, Z.-K. J. Mater. Chem. 2010, 20, 3626-3636. doi:10.1039/b924404b

32. Shi, M.-M.; Chen, H.-Z.; Sun, J.-Z.; Ye, J.; Wang, M. Chem. Commun. 2003, 1710-1711. doi:10.1039/b304141g

33. Gao, L.; Senevirathna, W.; Sauvé, G. Org. Lett. 2011, 13, 5354-5357. doi:10.1021/ol202211t

34. Senevirathna, W.; Sauvé, G. J. Mater. Chem. C 2013, 1, 6684-6694. doi:10.1039/c3tc31377h

35. delPozo, J.; Carrasco, D.; Pérez-Temprano, M. H.; García-Melchor, M.; Álvarez, R.; Casares, J. A.; Espinet, P. Angew. Chem., Int. Ed. 2013, 52, 2189-2193. doi:10.1002/anie.201209262

36. Meana, I.; Albéniz, A. C.; Espinet, P. Adv. Synth. Catal. 2010, 352, 2887-2891. doi:10.1002/adsc.201000430

37. Pavia, D. L.; Lampman, G. M.; Kriz, G. S.; Vyvyan, J. R. Introduction to Spectroscopy; Brooks: Belmont, CA, U.S.A., 2009.

38. Teets, T. S.; Partyka, D. V.; Updegraff, J. B.; Gray, T. G. Inorg. Chem. 2008, 47, 2338-2346. doi:10.1021/ic701190g

39. Rigaku Corp. (2001). CrystalClear, T. W., Texas, USA.

40. Otwinowski, Z.; Minor, W. In Macromolecular Crystallography, Pt A; Carter, C. W., Jr.; Sweet, R. M., Eds.; Methods in Enzymology, Vol. 276; 1997; pp 307-326.

41. Sheldrick, G. M. Acta Crystallogr., Sect. A: Found. Crystallogr. 2008, 64, 112-122. doi:10.1107/S0108767307043930

42. SHELXTL, Bruker Advanced X-ray Solutions, Version 6.14; Madison, WI, U.S.A., 2000.

43. Sheldrick; G. M. U. o. G.: Germany, http://shelx.uni-ac.gwdg.de/SHELX/.

44. Hübschle, C. B.; Sheldrick, G. M.; Dittrich, B. J. Appl. Crystallogr. 2011, 44, 1281-1284. doi:10.1107/S0021889811043202

\section{License and Terms}

This is an Open Access article under the terms of the Creative Commons Attribution License (http://creativecommons.org/licenses/by/4.0), which permits unrestricted use, distribution, and reproduction in any medium, provided the original work is properly cited.

The license is subject to the Beilstein Journal of Organic Chemistry terms and conditions:

(http://www.beilstein-journals.org/bjoc)

The definitive version of this article is the electronic one which can be found at: doi:10.3762/bjoc. 12.182 